\title{
Puncture of an import gasoline pipeline - spray effects may evaporate more fuel than a Buncefield-type tank overfill event
}

\author{
Hedlund, Frank Huess; Pedersen, Jan Boier; Sin, Gürkan; Garde, Frits G.; Kragh, Eva K.; Frutiger, \\ Jérôme
}

\author{
Published in: \\ Process Safety and Environmental Protection
}

Link to article, DOI:

10.1016/j.psep.2018.11.007

Publication date:

2019

Document Version

Peer reviewed version

Link back to DTU Orbit

Citation (APA):

Hedlund, F. H., Pedersen, J. B., Sin, G., Garde, F. G., Kragh, E. K., \& Frutiger, J. (2019). Puncture of an import gasoline pipeline - spray effects may evaporate more fuel than a Buncefield-type tank overfill event. Process Safety and Environmental Protection, 122, 33-47. https://doi.org/10.1016/j.psep.2018.11.007

\section{General rights}

Copyright and moral rights for the publications made accessible in the public portal are retained by the authors and/or other copyright owners and it is a condition of accessing publications that users recognise and abide by the legal requirements associated with these rights.

- Users may download and print one copy of any publication from the public portal for the purpose of private study or research.

- You may not further distribute the material or use it for any profit-making activity or commercial gain

- You may freely distribute the URL identifying the publication in the public portal 


\section{Accepted Manuscript}

Title: Puncture of an import gasoline pipeline - spray effects may evaporate more fuel than a Buncefield-type tank overfill event

Authors: Frank Huess Hedlund, Jan Boier Pedersen, Gürkan Sin, Frits G. Garde, Eva K. Kragh, Jérôme Frutiger

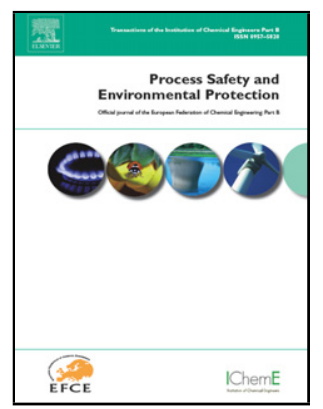

PII:

DOI:

Reference:

S0957-5820(18)30615-3

To appear in: $\quad$ Process Safety and Environment Protection

Received date: $\quad 15$ August 2018

Revised date: $\quad 7$ November 2018

Accepted date: $\quad 9$ November 2018

Please cite this article as: Hedlund FH, Pedersen JB, Sin G, Garde FG, Kragh EK, Frutiger J, Puncture of an import gasoline pipeline - spray effects may evaporate more fuel than a Buncefield-type tank overfill event, Process Safety and Environmental Protection (2018), https://doi.org/10.1016/j.psep.2018.11.007

This is a PDF file of an unedited manuscript that has been accepted for publication. As a service to our customers we are providing this early version of the manuscript. The manuscript will undergo copyediting, typesetting, and review of the resulting proof before it is published in its final form. Please note that during the production process errors may be discovered which could affect the content, and all legal disclaimers that apply to the journal pertain. 


\section{Puncture of an import gasoline pipeline - spray effects may evaporate more fuel than a Buncefield-type tank overfill event}

Frank Huess Hedlund ${ }^{a, b} *$, Jan Boier Pedersen ${ }^{a}$, Gürkan Sin ${ }^{c}$, Frits G. Garde, Eva K. Kragh ${ }^{a}$, Jérôme Frutiger ${ }^{c}$

a) COWI, Parallelvej 2, DK-2800 Kongens Lyngby, Denmark

b) DTU/Compute. Technical University of Denmark DK-2800 Kongens Lyngby, Denmark.

c) PROSYS Research Center, Department of Chemical and Biochemical Engineering, Technical University of Denmark (DTU), Søltofts Plads, Building 229, DK-2800 Kgs. Lyngby, Denmark

*corresponding author

\section{Abstract}

This paper is concerned with evaporation of moderately volatile liquids, gasoline in particular, due to spray generation, liquid fragmentation and fountain effects following accidental puncture of a pressurized pipeline. Hazard analysis predicts that extensive evaporation will take place. The paper examines a typical fuel depot receiving gasoline from a ship at a nearby port via an above-ground pipeline. For comparative purposes, two types of accidental release during import are considered: 1) The receiving tank overflows in a worst-case Buncefield-type event (baseline). 2) The import pipeline is punctured and a jet of liquid discharges upwards.

The paper examines pipeline import of three substances, hexane, octane and winter gasoline. Hazard analysis using the PHAST software suite indicates that the amount of fuel evaporated from the pipeline puncture scenarios greatly exceeds the amount evaporated in a tank overfill event for all three substances, gasoline in particular. Proper modelling of evaporation of wide-range multicomponent mixtures such as gasoline is challenging however. PHAST's simplified thermodynamic modelling of properties of mixtures may be a source of error. A PHAST-based stand-alone spray evaporation model with advanced thermodynamic capability is developed. Results indicate that PHAST does 
indeed overestimate evaporation of mixtures. Still, model output shows that evaporation following pipeline puncture may exceed the evaporation from a Buncefield-type tank overfill event by a factor of two or more. This finding is significant as evaporation from pipeline puncture scenarios appear largely overlooked in hazard analysis. The finding may lead to a fundamental reappraisal of the hazard potential of fuel depots and pipelines.

- 251 words

Keywords: Major accident hazard; Onshore pipelines; Spray release, Consequence models, Fuel depot, Worst design event 


\section{Introduction}

Before 2005, the storage of gasoline in large above-ground tanks was thought to present rather limited risks to neighbours. The worst design event associated with a tank farm was believed to be a large pool fire following tank failure. Predicted hazard distances rarely exceeded $200 \mathrm{~m}$ [1], [2].

In 2005, an incident at the UK Buncefield fuel depot fundamentally changed the perceived hazard potential of gasoline fuel depots - the worst event became a vapour cloud explosion. The sequence of events at Buncefield can be summarized as follows: During a fuel import, a gasoline tank overfilled. Large amounts of gasoline flowed from breather openings in the tank roof and fell (cascaded) into the bund area. The volatile components in the gasoline vaporized rapidly and mixed with air to form a flammable mixture that subsequently exploded with devastating force.

The Buncefield explosion took place early Sunday morning, the area was quiet and there were no fatalities. While nobody was killed, the potential for a masscasualty event is obvious. Property damage was extensive. The fuel depot was close to some 630 businesses employing about 16,500 people. The premises of 20 businesses employing 500 people were destroyed and the premises of 60 businesses employing 3,500 people were severely damaged [3]. Buildings as far as 8 kilometres from the depot, suffered lesser damage, such as broken windows, and damaged walls and ceilings. Costs were estimated at about $£ 1$ billion [2].

The Buncefield incident had major implications for hazard analysis of fuel depots. The new insights can be summarized as: 1) An unforeseen release mechanism (overflow and cascading), leading to extensive evaporation of the lighter components of gasoline; and 2) An unforeseen explosion mechanism, producing destructive blast pressures even though the area around the depot was considered rather open and uncongested. The Buncefield incident led to a worldwide re-appreciation of the major hazard potential of fuel depots. The concern now became a Buncefield-type tank overfill event, late ignition and a so-called Open Flammable Cloud Explosion (OFCE) [2], [4]-[6]. The term Unconfined Vapour Cloud Explosion (UVCE) has been used extensively in the past but may give way to the term Open Flammable Cloud Explosion (OFCE). It has been argued that the word 'unconfined' should be dropped in favour of 'open' to emphasise that for many past UVCE incidents there was in fact some degree of confinement provided by obstacles which prevented the unhindered movement of the flammable cloud ahead of the flame as the combustion process developed [2]

This paper draws attention to another release mechanism capable of producing a large vapour cloud, which to the best of our knowledge has received little attention in the literature: Puncture of an import pipeline results in a jet spray of liquid gasoline that discharges upwards and forms a fountain with many droplets, which leads to extensive evaporation of the lighter components of gasoline. We present evidence to suggest that this spray scenario may evaporate more fuel than a Buncefield-type overfill event. Hence, it may 
constitute a worst-case scenario in fuel depot hazard analysis that is currently overlooked.

We are of the opinion that the pipeline puncture scenario is particularly relevant for hazard analysis of fuel depots at marine terminals. Import or export pipelines are often located above ground and may be vulnerable to external impact, e.g. dropped objects, or for pipe bridges above road crossings, collision impact by heavy vehicle.

A gasoline pipeline risk analysis approach published in 1999 [7] considered a pipeline leak or rupture forming a pool of gasoline from which evaporation and ignition resulted in a flash fire which burned back to produce a pool fire. The study assumed that soil permeability determined the size of the unignited pool and hence the rate of evaporation feeding a vapour cloud. Gasoline was assumed to be absorbed into the ground after which it presented no safety risk. Estimated pools were rather small, for a rupture with a release rate of $205 \mathrm{~kg} / \mathrm{s}$ and delayed ignition, the maximum pool diameter was $100 \mathrm{~m}$. Evaporation from spray and fountain effects were not considered.

Another pipeline risk analysis approach also published in 1999 [8] considered the length of throw of a jet of gasoline, which could douse occupied buildings and later engulf them in flames. Spray formation was briefly mentioned but evaporation was not addressed. In 2002, the UK HSE published a large set of pipeline incident reports [9]. For non-flashing liquids only pool fires were considered although the study suggested that spray releases appeared to be significantly more hazardous. A risk analysis of a Polish gasoline cross country pipeline published in 2006 [10] did not consider spray evaporation either.

More recent oil and gas pipeline risk studies in 2015 and 2016 [11], [12] do not address spray evaporation of liquids with volatile components. A 2017 study on pipeline accidents and land-use planning [13] does not appear to rule out an explosion following the accidental release of "volatile liquid materials" but the discussion lacks precision, as the study is based on analysis of historical data and struggles with incomplete information and other limitations of (often discontinued) accident databases. The work of [14] presents an exception to this general picture, as they briefly attempt to extend their models of tank overfill events to cover spray releases also.

In conclusion, rapid evaporation of large quantities of flammable vapours from puncture of a gasoline pipeline due to spray and fountain effects is a scenario currently given little or no consideration in pipeline risk analysis studies.

The main thrust of this work relates to hazard analysis of evaporation from a spray release of gasoline. We examine the generation of vapour following a puncture of a pressurized gasoline import pipeline to a fuel depot. For perspective, we compare the results with the amount evaporated in case the same import pipeline would result in a Buncefield-type overfill scenario. The purpose is to examine the relevance of the spray release scenario as major hazard scenario and potential worst design event to be considered in hazard analysis of fuel depots. To our knowledge, no previous work has addressed this topic. 
A representation of the composition of gasoline is required before modelling and process hazard analysis can take place. This is no trivial task as gasoline is a complex mixture of hundreds of hydrocarbons with very different boiling points. Earlier experimental and simulation work, see e.g. the comprehensive research program on vapour cloud formation reported in [15], used hexane to represent gasoline in order to simplify analysis, or at best used a fourcomponent mixture of butane, pentane, hexane and decane. A second thrust of this paper is to define a generic wide-range multi-component hydrocarbon composition with properties similar to a typical winter gasoline for use in consequence modelling. To our knowledge, this contribution is also novel.

There are a variety of consequence modelling software suites available [16]. This work uses the commercially available software suite for process hazard analysis PHAST developed by DNV GL. PHAST is referred to in international peer-reviewed journals, in model benchmark analysis [17], in post-accident comparative analysis [18] and in consequence model validation studies [19], [20]. Specifically, we point to articles on validation of PHAST's models for spray releases [21], [22].

We have certain a priori reservations regarding the ability of well-established hazard analysis software suites to handle wide-range multi-component mixtures such as gasoline. The approach taken in PHAST to thermodynamic modelling of mixture properties is simplified, essentially a mixture is represented by a "pseudo-pure component". A third thrust of this work is therefore to construct a stand-alone spray evaporation model faithful to the one implemented in PHAST and then enhance this model with advanced thermodynamic modelling capability. The purpose is to examine the effect of improved thermodynamic modelling of mixtures on the estimated amount of evaporation for spray releases.

It is true that PHAST provides a multi-component version with more advanced thermodynamic modelling. The multi-component version does not model rainout however. The model is therefore not suitable for estimation of evaporation of moderately volatile liquids for which the rainout fraction is significant. A custom model is required.

There are numerous theoretical and practical challenges associated with extracting a single stand-alone model from a suite of integrated models. Juxtaposition of the results from PHAST and the PHAST-based Stand-Alone Model (SAM) will provide a crude but nonetheless essential indication of the magnitude of any errors potentially caused by simplified thermodynamic modelling. To our knowledge, no previous study has attempted advanced thermodynamic modelling of spray evaporation of wide-range multi-component mixtures for accidental loss of containment events. 


\section{Material and methods}

\subsection{Overview}

The research methodology is summarized in Figure 1. Accordingly, the work reported here comprises the following steps:

1 Definition of release scenarios, input parameters and substance property models

1.1 Description of a generic fuel depot configuration and a typical gasoline import situation

1.2 Specification of two types loss of containment (LOC) events during the gasoline import: 1) a Buncefield-type tank overfill scenario (baseline), and 2) puncture of the pressurized import pipeline

1.3 Definition of a generic multi-component hydrocarbon composition to represent a typical winter gasoline

2 Estimation of evaporation from a Buncefield-type over-fill scenario based on large-scale experimental work reported by HSE/HSL and FABIG

3 Estimation of evaporation from pipeline puncture scenarios, using:

3.1 The PHAST software suite's (ver. 8.0) recommended settings, i.e. the default release rate and spray evaporation models and the available thermodynamic package for multi-component mixtures

3.2 A stand-alone PHAST-like spray evaporation model faithful to the one in PHAST but enhanced with advanced thermodynamic modelling of multi-component mixtures, implemented in MATLAB software. 


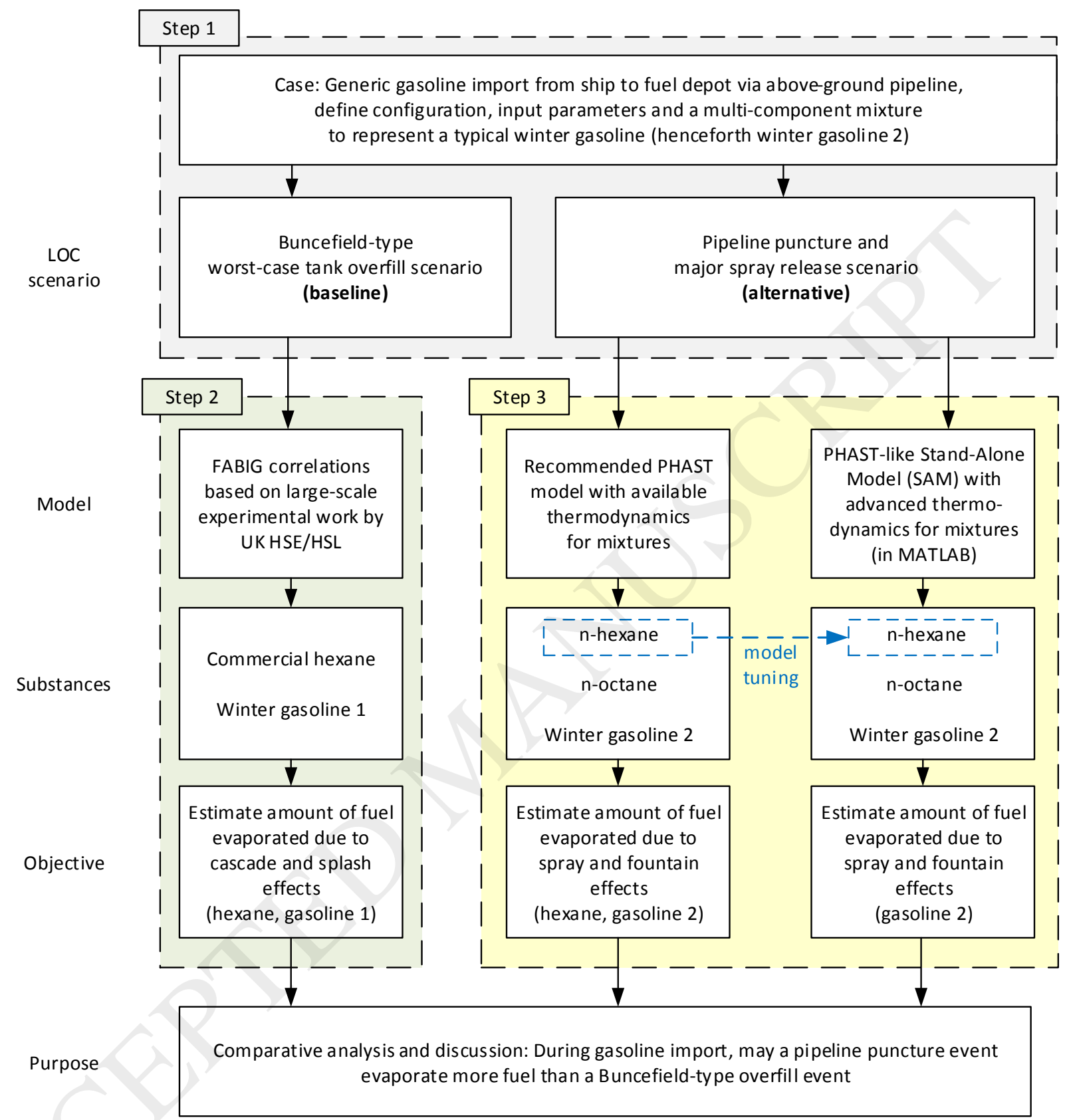

Figure 1. Methodology and purpose of this study 


\subsection{Step 1: Definition of model scenarios and input parameters}

\subsubsection{Configuration of generic fuel depot and a typical gasoline import situation}

Fuel depots typically receive gasoline from a marine tanker at a nearby port or from a distant tank farm via a cross-country pipeline. This study considers imports of gasoline from tankers at ports only. Typically, import pipelines at ports are a few kilometres long and pressures are in the 10-15 barg range, whereas the length of cross-country pipelines are measured in hundreds of kilometres and pressures often exceed $100 \mathrm{barg}$. Hence, if spray effects are relevant for pipelines at port terminals, they are even more so for cross-country pipelines with much higher internal pressures.

We have assumed a typical import rate of $1,000 \mathrm{~m}^{3} / \mathrm{h}$. For perspective, the import rate (via cross-country pipeline) to the overflowing tank at Buncefield was $550 \mathrm{~m}^{3} / \mathrm{h}$, increasing to $890 \mathrm{~m}^{3} / \mathrm{h}[1]$.

A fuel terminal informed the authors, that certain refineries ship warm gasoline, which even after a 2-3 day Atlantic Sea voyage during wintertime can be warm upon arrival. We have assumed a liquid temperature of $20^{\circ} \mathrm{C}$ for winter gasoline. For details, refer to Table 1, section A.

\subsubsection{Specification of tank overfill and pipeline puncture scenarios}

The Buncefield-type tank overfill scenario is assumed to result from a failure of the receiving tank's level indication and overfill protection systems. The entire import flow rate runs from openings in the tank roof and forms a free cascade that is projected away from the tank wall. The cascade and splashing at the base lead to extensive evaporation of the lighter components of gasoline. For details, refer to Table 1, section B.

The pipeline puncture scenario is assumed to result from some external impact, e.g. truck driver forgets to lower the crane arm and collides with a pipe bridge (road overpass) about $100 \mathrm{~m}$ from the ship. A jet of liquid discharges upwards through an orifice, forming a fountain with many droplets, which leads to extensive evaporation of the lighter components of gasoline. Four hole sizes are considered for which the combination of hole size and pipeline backpressure (orifice pressure) allows the release of 95\%, 75\%, 50\% and $25 \%$ of the nominal import flow rate. Two pipeline lengths are considered. Their different friction loss profiles result in different orifice pressures at the puncture location. For details, refer to Table 1, section C.

Liquid not evaporated while airborne will rain-out on the ground and form a pool from which further evaporation will take place. The rate of evaporation is a function of the pool area, which is unknown. To simplify analysis, pool evaporation is ignored. Effects of wind on evaporation while droplets are airborne are also ignored, only calm conditions are considered. 


\subsection{Step 2: Estimation of evaporation from Buncefield- type tank overfill scenario}

Our modelling of the amount evaporated in a Buncefield-type overfill event is based on the results of large-scale experimental work carried out by the UK HSE/HSL [15], in particular the empirical correlations reported by the Fire and Blast Information Group (FABIG) Technical Note 12 [14], [23]. The FABIG source provides empirical correlations for hexane and winter grade gasoline.

An examination of the background study [15] reveals that the correlation for hexane is based on experiments with commercial hexane, i.e. a mixture of several hexane isomers. The correlation for winter grade gasoline is based on experiments with commercial hexane and supplementary experiments with other mixtures. We consider the results from this ambitious research program to provide the best guidance currently available for estimation of worst-case evaporation resulting from a tank overfill event.

Table 1. Definition of loss-of-containment (LOC) scenarios

A) Import pipeline and fuel transfer

\begin{tabular}{|ll|}
\hline Nominal import flow rate & $1,000 \mathrm{~m}^{3} / \mathrm{h}$ \\
\hline Pipeline lengths considered & $1,000 \mathrm{~m}$ and $2,000 \mathrm{~m}$ \\
Pressure source & Pump at marine tanker \\
Temperature of imported liquid & $20{ }^{\circ} \mathrm{C}$ \\
Pipeline internal diameter & $250 \mathrm{~mm}$ \\
Armatures in pipeline & 50 bends, 8 valves \\
\hline
\end{tabular}

B) Tank overflow scenarios

\begin{tabular}{|ll|}
\hline Liquids considered & Commercial hexane ${ }^{\mathrm{a}}$, winter grade gasoline ${ }^{\mathrm{a}, \mathrm{b}}$ \\
\hline Flow rate of overtopping liquid & $1,000 \mathrm{~m}^{3} / \mathrm{h}$ \\
Temperature of liquid & $20{ }^{\circ} \mathrm{C}$ \\
Tank diameter & $29 \mathrm{~m}$ \\
Tank height & $20 \mathrm{~m}$ \\
Ambient conditions & Calm wind, $10{ }^{\circ} \mathrm{C}$ \\
Evaporation from rainout fraction & Ignored \\
\hline
\end{tabular}

${ }^{a}$ The compositions used in large-scale experimental work [15]

${ }^{b}$ Referred to as gasoline 1

\section{C) Pipeline puncture scenarios}

\begin{tabular}{|ll|}
\hline Liquids considered & $\mathrm{n}$-hexane, $\mathrm{n}$-octane, winter gasoline ${ }^{\mathrm{a}}$ \\
\hline $\begin{array}{l}\text { Release rate (expressed as fraction of } \\
\text { nominal import flow rate) }\end{array}$ & $25 \%, 50 \%, 75 \%$ and $95 \%$ \\
Pipeline length & $1,000 \mathrm{~m}$ and $2,000 \mathrm{~m}$ \\
\hline
\end{tabular}




\begin{tabular}{|ll|}
\hline Angle of jet from horizontal & $45^{\circ}$ and $80^{\circ}$ \\
Temperature of liquid & $20^{\circ} \mathrm{C}$ \\
Ambient conditions & Calm wind, $10{ }^{\circ} \mathrm{C}$ \\
Evaporation from rainout fraction & Ignored \\
\hline
\end{tabular}

${ }^{a}$ Wide-range multi-component mixture with properties similar to a typical winter gasoline. This composition is referred to as gasoline 2.

\subsection{Estimation of evaporation from of pipeline puncture scenarios}

\subsubsection{Spray evaporation using PHAST}

PHAST modelling of evaporation from a pipeline puncture and spray release is described in the PHAST technical documentation [24].

It comprises three steps:

1 A discharge model based on Bernoulli's equation for incompressible fluids.

2 A droplet formation model based on an aerodynamic break-up mechanism. The Sauter mean droplet diameter is calculated based on the work of [25]

3 An aerosol jet dispersion and evaporation model-based on the work of [26].

The core of the droplet evaporation model is the solution of differential equations describing droplet mass and temperature change due to droplet evaporation. Evaporation terminates when the droplet trajectory intercepts with ground level, known as droplet rainout. For spray releases of mixtures such as gasoline, PHAST represents the mixture with a pseudo-pure component The PHAST thermodynamic property model for the mixture is based on the AIChE DIPPR database for which details are available in [27].

\subsubsection{Spray evaporation using PHAST-based stand-alone model}

A Stand-Alone Model (SAM) for spray release evaporation from pipeline puncture has been implemented in MATLAB, a computing environment provided by MathWorks [28]. The SAM shares the same theoretical foundation and takes the same approach as PHAST. SAM output is tuned to PHAST output for selected scenarios with pure substances. The aim has been to provide an as faithful representation of the PHAST model as possible, within the time and budget constraints of this project, which gives similar results when applied to spray releases of pure substances. 
The SAM is then enhanced with advanced thermodynamic modelling capability for mixtures, a capability PHAST has not. The advanced thermodynamic modelling of mixture compositions is based on the GERG-2008 multiparameter wide-range Equation of State $(\mathrm{EoS})$ for natural gases and mixtures [29]. GERG-2008 widely known to be one of the most accurate and reliable property models for fuel mixtures. It has been used to calculate mixture properties for various technical applications. In particular, it is used to model liquid hydrocarbon mixtures in industrial chemical processes and thermodynamic cycles. GERG-2008 is based on an explicit formulation of the Helmholtz free energy as function of density, temperature and composition. It allows calculating real mixture properties such as liquid phase and vapour phase pressures, densities, enthalpies, entropies as well as heat capacities. For details, refer to Appendix A.

A major challenge for the PHAST-based Stand-Alone Model arises because some of PHAST's computations of energy balance, mechanical turbulent mixing with ambient air and droplet trajectory take place in the Unified Dispersion Model (UDM) module [22], [30] of the PHAST software suite, not in the spray module. A stand-alone model of the UDM module is beyond the scope of the present work however. 


\section{Generic multi-component hydrocarbon composition similar to a typical winter gasoline}

Commercial gasoline is a mixture of a large number of hydrocarbons with different boiling points. The exact composition of gasoline is unknown and varies according to the crude oils from which it is produced, the type of processing units present at the refinery, how those units are operated and which hydrocarbon streams (blendstocks) the refinery opts to use when blending the final product.

In Europe, gasolines must meet the requirements set forth in EN 228 [31]. Important specifications relate to volatility and Research Octane Number (RON). The fuel volatility requirement, measured as Reid Vapour Pressure (RVP) at $37.8^{\circ} \mathrm{C}\left(100^{\circ} \mathrm{F}\right)$, reflects a compromise; on the ability to start a cold engine while at the same time avoid excessive evaporative losses of volatile organic compounds (VOCs), which are unwanted air pollutants. The fuel volatility specification varies according to geographical area and season, with higher volatility during winter. In Denmark, the maximum RVP is $70 \mathrm{kPa}$ summer and $95 \mathrm{kPa}$ winter. Refiners typically adjust the vapour pressure by adding butane $(\mathrm{C} 4)$ to the gasoline blend. Because the price of butane is lower than that of gasoline, refiners have an economic incentive in meeting the maximum permitted RVP.

At the refinery, the heavy virgin naphtha (HVN) fraction (mainly C7-C9) from crude oil distillation is processed in a reformer unit, which converts cyclic alkanes (naphtenes) and other hydrocarbons to unsaturated and ring-shaped aromatic compounds (e.g. benzene, toluene, ethyl-benzene, xylenes), which have much higher octane numbers. Refiners avoid feeding $\mathrm{C} 6$ to the reformer unit, in particular cyclohexane, as this would be converted to benzene, for which EN 228 sets a maximum content of one percent volume fraction due to its adverse health effects. The stream leaving the reformer unit is known as reformate. Refiners typically adjust the octane number of the gasoline blend by adding reformate.

The light virgin naphtha (LVN) fraction (mainly C5-C6) has a high content of straight chain alkanes with low octane numbers. Some refineries have an isomerization unit, which convert them into branched isomers, which have higher octane numbers. The stream leaving the isomerization units is known as isomerate. Refiners can use the rather volatile isomerate as a base blendstock in gasoline blending.

The description above is highly simplified. There are many other options, and the economic performance of the refinery depends much on its ability to optimize gasoline blending operations.

Because winter gasolines contain more volatiles, we select a typical Danish 95 octane winter gasoline composition for our study. We have communicated (personal communication) with a refinery on gasoline blending operations and the blendstocks used, and with a large laboratory which undertakes certification 
work that commercial gasolines meet specifications. The refinery and the laboratory have kindly supplied relevant information for our gasoline composition work, but both wish not to be named.

The refinery informs that the typical main blendstocks for gasoline formulation are isomerate, reformate and butane. Refer to Table 3 for stream properties. Isomerate is rather volatile with $85 \%$-vol evaporated at $70{ }^{\circ} \mathrm{C}$, while only $4 \%$ vol of the reformate has evaporated at this temperature. The laboratory provided analysis results of two typical $95 \mathrm{RON}$ winter gasoline formulations, here shown as Blend1 and Blend2 in Table 3. Blend1 contains much isomerate. Blend 2 has less isomerate and some low-RON straight chain LVN paraffins, which the refinery likely had in surplus. Hence, Blend2 has a higher content of reformate to meet the RON specification, and a higher butane content to meet the upper RVP limit. The two blends are typical and both meet the 95 RON winter gasoline specification but because of different formulations, their $\mathrm{C} 4$ C11 distributions differ. The two blends illustrate the inherent compositional variability of "commercial gasoline" and the practical challenges associated with defining a model composition based on pure substances.

The isomerate is too volatile for the RON to be determined experimentally. Instead, the RON is computed based on gas chromatograph analysis which provides detailed information on the composition. Based on this information and an additional iso-pentane blendstock, we define a wide-range multicomponent mixture to represent a generic European winter gasoline, named Gen13 in Table 2.

The initial Buncefield report [1] grouped butanes, pentanes and hexanes as the 'lighter components' in gasoline. Our a-priori expectation is therefore that the most relevant compounds to consider for spray and fountain evaporation are in the C4-C6 range. While there is little doubt that the highly volatile $\mathrm{C} 4$ fraction will evaporate with ease, good modelling of evaporation of the moderately volatile $\mathrm{C} 5$ and $\mathrm{C} 6$ fractions appears essential. The isomers of these fractions have a wide range of boiling points, e.g. $28-49{ }^{\circ} \mathrm{C}$ for $\mathrm{C} 5$ alkanes and $50-81{ }^{\circ} \mathrm{C}$ for $\mathrm{C} 6$ alkanes. An accurate representation of these compounds, in particular the most volatile alkane isomers, may therefore be important. The Gen13 model composition attempts to do this. The composition is modelled on Blend1, which had the highest content of C4-C6 volatiles. Due to unavailability of thermodynamic interaction parameters in the NIST REFPROP database [32] for several isomers, this study uses a simplified composition, Sim10, to represent $95 \mathrm{RON}$ winter gasoline, henceforth referred to as gasoline 2.

Table 2. Two example compositions to represent a generic European RON95 winter gasoline. This paper uses the simplified 10-component mixture (Sim10), also referred to as gasoline 2

\begin{tabular}{|lll|l|l|}
\hline Component & CAS & $\begin{array}{l}\text { BP } \\
{ }^{\circ} \mathrm{C}\end{array}$ & $\begin{array}{l}\text { Gen13 } \\
\% \text {-vol }\end{array}$ & $\begin{array}{l}\text { Sim10 } \\
\% \text {-vol }\end{array}$ \\
\hline Iso-Butane & $75-28-5$ & -12 & 3.58 & 3.58 \\
n-Butane & $106-97-8$ & -1 & 6.58 & 6.58 \\
\hline
\end{tabular}




\begin{tabular}{|lll|l|l|}
\hline iso-Pentane & $78-78-4$ & 28 & 17.88 & 17.88 \\
Cyclopentane & $287-92-3$ & 49 & - & 9.44 \\
\hline 2.2-Dimetylbutane & $75-83-2$ & 50 & 4.23 & - \\
2-Methylpentane & $107-83-5$ & 60 & 10.42 & - \\
n-Hexane & $110-54-3$ & 69 & - & 8.94 \\
Methylcyclopentane & $96-37-7$ & 72 & 3.73 & - \\
CycloHexane & $110-82-7$ & 81 & 5.82 & 5.82 \\
\hline 2-Methylhexane & $591-76-4$ & 92 & 3.26 & - \\
n-Heptane & $142-82-5$ & 98 & - & 3.26 \\
Toluene & $108-88-3$ & 111 & 18.41 & 25.00 \\
n-Octane & $111-65-9$ & 126 & 3.45 & 10.00 \\
m-Xylene & $108-38-3$ & 139 & 15.06 & - \\
n-Nonane & $111-84-2$ & 151 & 5.44 & 9.49 \\
Decane & $124-18-5$ & 174 & 2.12 & - \\
\hline
\end{tabular}

Table 3. Characteristic properties of typical gasoline blendstocks and two typical commercial 95 RON winter gasoline blends. For comparison, the properties of two suggested generic compositions are also shown.

\begin{tabular}{|c|c|c|c|c|c|c|c|c|}
\hline & & \multicolumn{3}{|c|}{ Typical blendstock } & \multicolumn{2}{|c|}{$\begin{array}{l}\text { Commercial } 95 \text { RON } \\
\text { raw }{ }^{a} \text { winter gasoline }\end{array}$} & \multicolumn{2}{|c|}{\begin{tabular}{|l|}
$\begin{array}{l}\text { Multi-component } \\
\text { model mixtures }\end{array}$ \\
\end{tabular}} \\
\hline & & Isomerate & Reformate & Butane & Blend 1 & Blend 2 & Gen 13 & Simple10 \\
\hline Density at $15^{\circ} \mathrm{C}$ & $\mathrm{kg} / \mathrm{m} 3$ & 677 & 810 & 577 & 738 & 745 & & \\
\hline Evaporated at $70^{\circ} \mathrm{C}$ & $\%$-vol & 84.6 & 3.6 & & $35-37$ & $35-37$ & & \\
\hline Evaporated at $100^{\circ} \mathrm{C}$ & $\%$-vol & 97.3 & 13.6 & & $58-59$ & $58-59$ & & \\
\hline Final Boiling Point & ${ }^{\circ} \mathrm{C}$ & & 192 & & $188-190$ & $188-190$ & & \\
\hline Reid Vapour Pressure & $\mathrm{kPa}$ & 73.5 & 29.4 & 315.0 & $85-88^{a}$ & $85-88^{a}$ & 91.4 & 90.2 \\
\hline Research Octane Numbe & & 88.3 & 98.8 & 95.4 & $93.7^{\mathrm{a}}$ & $93.7^{\mathrm{a}}$ & & \\
\hline Mole weight & $\mathrm{g} / \mathrm{mol}$ & & & 58.0 & 92.9 & 93.4 & 87.5 & 84.9 \\
\hline Paraffins & $\%$-vol & 74.2 & 31.2 & 100.0 & 54.7 & 52.1 & & \\
\hline Aromatics & $\%$-vol & 0.0 & 67.2 & & 36.0 & 41.2 & & \\
\hline Naphtenes & $\%$-vol & 26.5 & 0.9 & & 9.0 & 6.0 & & \\
\hline Benzene & $\%$-vol & & 1.5 & & 0.9 & $1.1^{\mathrm{a}}$ & & \\
\hline Total C3 & $\%$-vol & & & 1.8 & & & & \\
\hline Total C4 & $\%$-vol & 0.5 & 4.2 & 97.4 & 8.1 & 11.9 & 10.2 & 10.2 \\
\hline Total C5 & $\%$-vol & 33.8 & & 0.7 & 19.5 & 16.3 & 18.6 & 27.3 \\
\hline Total C6 & $\%$-vol & 60.4 & & 0.1 & 23.0 & 15.9 & 23.2 & 14.8 \\
\hline Total C7 & $\%$-vol & 3.9 & & & 21.5 & 25.8 & 21.9 & 28.3 \\
\hline Total C8 & $\%$-vol & 1.5 & & & 15.9 & 17.7 & 18.7 & 10.0 \\
\hline Total C9 & $\%$-vol & & & & 9.0 & 9.3 & 5.3 & 9.5 \\
\hline
\end{tabular}




\begin{tabular}{|l|l|ll|l|} 
Total C10 & $\%$-vol & & 2.0 & 2.0 \\
Total C11+ & $\%$-vol & 0.4 & 0.5 & 2.1 \\
\hline
\end{tabular}

${ }^{a}$ Raw gasoline refers to qualities handled at depots. Ethanol (5\%-vol) is added later in the distribution chain, raising the octane number to 95 RON and the RVP to just below 95 $k P a$ at the pump. 


\section{$4 \quad$ Results}

FABIG estimation of evaporation for a Buncefield-type tank overfill scenario is shown in Table 4.

Table 4. Vapour generation in case of Buncefield-type tank overfill event (baseline), import rate $1,000 \mathrm{~m}^{3} / \mathrm{h}$

\begin{tabular}{|l|lll|}
\hline Model substance & $\begin{array}{l}\text { Import rate } \\
{[\mathrm{kg} / \mathrm{s}]}\end{array}$ & $\begin{array}{l}\text { Evaporation } \\
\text { rate }^{\mathrm{a}}[\mathrm{kg} / \mathrm{s}]\end{array}$ & $\begin{array}{l}\text { Fraction of import } \\
\text { rate evaporated [-] }\end{array}$ \\
\hline Hexane $^{\mathrm{b}}$ & 182 & 35.8 & 0.197 \\
Winter grade gasoline $^{\mathrm{c}}$ & 206 & 40.7 & 0.198 \\
Heavy reformate $^{\mathrm{d}}$ & 225 & 9.53 & 0.042 \\
\hline
\end{tabular}

${ }^{a}$ Estimates based on experimental and theoretical work [15] and correlations [14]

${ }^{b}$ Based on experimental work with commercial hexane (mixture of hexane isomers).

c Also referred to in this article as "gasoline 1". Correlation is likely based on experimental work with model mixture of butane, pentane, hexane and decane.

${ }^{d}$ Example of low-volatility substance, correlation is available but experimental basis and composition are unclear.

The results of the PHAST modelling of pipeline puncture scenarios are shown in Table 5. Beside the evaporation rate and the fraction evaporated, also the orifice diameter, the release rate, the estimated back-pressure in the pipeline required to attain the scenario release rate, and the initial droplet diameter are tabulated. Unsurprisingly, a reduction in the orifice diameter gives a smaller release rate and a higher orifice back-pressure, which in turn gives a more efficient droplet atomization (smaller droplet diameter) and a more pronounced droplet evaporation. It is noteworthy that for relatively modest orifice backpressures, say larger than 4 barg, the model predicts almost complete evaporation of spray releases of moderately volatile liquids such as hexane and winter gasoline. 


\begin{tabular}{|c|c|c|c|c|c|c|c|c|c|c|c|c|c|}
\hline \multirow[b]{2}{*}{$\begin{array}{l}\text { Subs } \\
\text { tanc } \\
\mathrm{e}\end{array}$} & \multirow[b]{2}{*}{$\begin{array}{l}\text { Pip } \\
\text { elin } \\
\text { e } \\
\text { len } \\
\text { gth } \\
{[\mathrm{m}]}\end{array}$} & \multirow[b]{2}{*}{$\begin{array}{l}\text { Lea } \\
\mathrm{k} \\
\text { (fra } \\
\text { ctio } \\
\mathrm{n} \text { of } \\
\text { imp } \\
\text { ort } \\
\text { rate } \\
\text { ) } \\
{[\%]} \\
\end{array}$} & \multirow[b]{2}{*}{$\begin{array}{l}\text { Orif } \\
\text { ice } \\
\text { dia } \\
\text { met } \\
\text { er } \\
{[\mathrm{m}} \\
\mathrm{m}]\end{array}$} & \multirow[b]{2}{*}{$\begin{array}{l}\text { Ori } \\
\text { fice } \\
- \\
\text { are } \\
\text { a } \\
{[\%]}\end{array}$} & \multirow[b]{2}{*}{$\begin{array}{l}\text { Ori } \\
\text { fice } \\
- \\
\text { pre } \\
\text { ssur } \\
\mathrm{e} \\
\text { [bar } \\
\mathrm{g}]\end{array}$} & \multirow[b]{2}{*}{$\begin{array}{l}\text { Rel } \\
\text { eas } \\
\mathrm{e} \\
\text { rate } \\
\\
{[\mathrm{kg}} \\
/ \mathrm{s}]\end{array}$} & \multirow[b]{2}{*}{$\begin{array}{l}\text { Initi } \\
\text { al } \\
\text { dro } \\
\text { plet } \\
\text { dia } \\
\text { met } \\
\text { er } \\
{[\mu \mathrm{m}} \\
]\end{array}$} & \multicolumn{3}{|c|}{ Angle to horizontal $45^{\circ}$} & \multicolumn{3}{|c|}{ Angle to horizontal $80^{\circ}$} \\
\hline & & & & & & & & $\begin{array}{l}\text { Evap } \\
\text { oratio } \\
\text { n rate } \\
{[\mathrm{kg} / \mathrm{s}]}\end{array}$ & $\begin{array}{l}\text { Fract } \\
\text { ion } \\
\text { of } \\
\text { relea } \\
\text { se } \\
\text { rate } \\
\text { evap } \\
\text { orate } \\
\mathrm{d} \\
{[-]} \\
\end{array}$ & $\begin{array}{l}\text { Fract } \\
\text { ion } \\
\text { of } \\
\text { impo } \\
\mathrm{rt} \\
\text { rate } \\
\text { evap } \\
\text { orate } \\
\mathrm{d} \\
{[-]} \\
\end{array}$ & $\begin{array}{l}\text { Evap } \\
\text { oratio } \\
\mathrm{n} \text { rate } \\
{[\mathrm{kg} / \mathrm{s}]}\end{array}$ & $\begin{array}{l}\text { Fract } \\
\text { ion } \\
\text { of } \\
\text { relea } \\
\text { se } \\
\text { rate } \\
\text { evap } \\
\text { orate } \\
\text { d } \\
{[-]} \\
\end{array}$ & \begin{tabular}{|l|} 
Fract \\
ion \\
of \\
impo \\
$\mathrm{rt}$ \\
rate \\
evap \\
orate \\
$\mathrm{d}$ \\
{$[-]$} \\
\end{tabular} \\
\hline $\begin{array}{l}\text { n- } \\
\text { hexa } \\
\text { ne }\end{array}$ & $\begin{array}{l}1,0 \\
00\end{array}$ & $\begin{array}{l}95 \\
\%\end{array}$ & 169 & $\begin{array}{l}46 \\
\%\end{array}$ & $\begin{array}{l}1.1 \\
9\end{array}$ & 179 & 461 & 36.5 & 0.20 & 0.19 & 44.5 & 0.25 & 0.24 \\
\hline $\begin{array}{l}\text { n- } \\
\text { hexa } \\
\text { ne }\end{array}$ & $\begin{array}{l}1,0 \\
00\end{array}$ & $\begin{array}{l}75 \\
\%\end{array}$ & 137 & $\begin{array}{l}30 \\
\%\end{array}$ & $\begin{array}{l}1.7 \\
0\end{array}$ & 140 & 323 & 45.1 & 0.32 & 0.24 & 58.0 & 0.41 & 0.31 \\
\hline $\begin{array}{l}\text { n- } \\
\text { hexa } \\
\text { ne }\end{array}$ & $\begin{array}{l}1,0 \\
00\end{array}$ & $\begin{array}{l}50 \\
\%\end{array}$ & 95 & $\begin{array}{l}14 \\
\%\end{array}$ & $\begin{array}{l}3.3 \\
1\end{array}$ & 94 & 166 & 68.2 & 0.72 & 0.36 & 89.0 & 0.95 & 0.47 \\
\hline $\begin{array}{l}\text { n- } \\
\text { hexa } \\
\text { ne }\end{array}$ & $\begin{array}{l}1,0 \\
00\end{array}$ & $\begin{array}{l}25 \\
\%\end{array}$ & 58 & $5 \%$ & $\begin{array}{l}5.9 \\
8\end{array}$ & 47 & 92 & 46.9 & 1.00 & 0.25 & 46.9 & 1.00 & 0.25 \\
\hline $\begin{array}{l}\text { n- } \\
\text { hexa } \\
\text { ne }\end{array}$ & $\begin{array}{l}2,0 \\
00\end{array}$ & $\begin{array}{l}95 \\
\%\end{array}$ & 168 & $\begin{array}{l}45 \\
\%\end{array}$ & $\begin{array}{l}1.2 \\
0\end{array}$ & 177 & 457 & 36.5 & 0.21 & 0.19 & 44.0 & 0.25 & 0.23 \\
\hline $\begin{array}{l}\text { n- } \\
\text { hexa } \\
\text { ne }\end{array}$ & $\begin{array}{l}2,0 \\
00\end{array}$ & $\begin{array}{l}75 \\
\%\end{array}$ & 130 & $\begin{array}{l}27 \\
\%\end{array}$ & $\begin{array}{l}2.1 \\
2\end{array}$ & 141 & 259 & 57.7 & 0.41 & 0.31 & 75.9 & 0.54 & 0.40 \\
\hline $\begin{array}{l}\text { n- } \\
\text { hexa } \\
\text { ne }\end{array}$ & $\begin{array}{l}2,0 \\
00\end{array}$ & $\begin{array}{l}50 \\
\%\end{array}$ & 86 & $\begin{array}{l}12 \\
\%\end{array}$ & $\begin{array}{l}4.9 \\
9\end{array}$ & 95 & 110 & 94.2 & 1.00 & 0.50 & 94.6 & 1.00 & 0.50 \\
\hline $\begin{array}{l}\text { n- } \\
\text { hexa } \\
\text { ne }\end{array}$ & $\begin{array}{l}2,0 \\
00\end{array}$ & $\begin{array}{l}25 \\
\%\end{array}$ & 51 & $4 \%$ & $\begin{array}{l}9.7 \\
7\end{array}$ & 47 & 56 & 46.8 & 1.00 & 0.25 & 46.8 & 1.00 & 0.25 \\
\hline $\begin{array}{l}\text { n- } \\
\text { octa } \\
\text { ne }\end{array}$ & $\begin{array}{l}1,0 \\
00\end{array}$ & $\begin{array}{l}95 \\
\%\end{array}$ & 169 & $\begin{array}{l}46 \\
\%\end{array}$ & $\begin{array}{l}1.2 \\
7\end{array}$ & 194 & 516 & 8.5 & 0.04 & 0.04 & 10.5 & 0.05 & 0.05 \\
\hline $\begin{array}{l}\text { n- } \\
\text { octa } \\
\text { ne }\end{array}$ & $\begin{array}{l}1,0 \\
00\end{array}$ & $\begin{array}{l}75 \\
\%\end{array}$ & 137 & $\begin{array}{l}30 \\
\%\end{array}$ & $\begin{array}{l}1.8 \\
1\end{array}$ & 152 & 362 & 11.1 & 0.07 & 0.05 & 14.6 & 0.10 & 0.07 \\
\hline $\begin{array}{l}\text { n- } \\
\text { octa } \\
\text { ne }\end{array}$ & $\begin{array}{l}1,0 \\
00\end{array}$ & $\begin{array}{l}50 \\
\%\end{array}$ & 95 & $\begin{array}{l}14 \\
\%\end{array}$ & $\begin{array}{l}3.5 \\
2\end{array}$ & 102 & 186 & 17.9 & 0.18 & 0.09 & 25.9 & 0.25 & 0.13 \\
\hline $\begin{array}{l}\text { n- } \\
\text { octa } \\
\text { ne }\end{array}$ & $\begin{array}{l}1,0 \\
00\end{array}$ & $\begin{array}{l}25 \\
\%\end{array}$ & 58 & $5 \%$ & $\begin{array}{l}6.3 \\
7\end{array}$ & 51 & 103 & 20.2 & 0.40 & 0.10 & 30.7 & 0.60 & 0.15 \\
\hline $\begin{array}{l}\text { n- } \\
\text { octa } \\
\text { ne }\end{array}$ & $\begin{array}{l}2,0 \\
00\end{array}$ & $\begin{array}{l}95 \\
\%\end{array}$ & 168 & $\begin{array}{l}45 \\
\%\end{array}$ & $\begin{array}{l}1.2 \\
8\end{array}$ & 193 & 512 & 8.5 & 0.04 & 0.04 & 10.5 & 0.05 & 0.05 \\
\hline $\begin{array}{l}\text { n- } \\
\text { octa } \\
\text { ne }\end{array}$ & $\begin{array}{l}2,0 \\
00\end{array}$ & $\begin{array}{l}75 \\
\%\end{array}$ & 130 & $\begin{array}{l}27 \\
\%\end{array}$ & $\begin{array}{l}2.2 \\
6\end{array}$ & 153 & 290 & 14.4 & 0.09 & 0.07 & 19.4 & 0.13 & 0.10 \\
\hline $\begin{array}{l}\text { n- } \\
\text { octa } \\
\text { ne }\end{array}$ & $\begin{array}{l}2,0 \\
00\end{array}$ & $\begin{array}{l}50 \\
\%\end{array}$ & 86 & $\begin{array}{l}12 \\
\%\end{array}$ & $\begin{array}{l}5.3 \\
1\end{array}$ & 103 & 124 & 27.4 & 0.27 & 0.13 & 41.2 & 0.40 & 0.20 \\
\hline $\begin{array}{l}\text { n- } \\
\text { octa } \\
\text { ne }\end{array}$ & $\begin{array}{l}2,0 \\
00\end{array}$ & $\begin{array}{l}25 \\
\%\end{array}$ & 51 & $4 \%$ & $\begin{array}{l}10 . \\
40\end{array}$ & 51 & 63 & 31.2 & 0.61 & 0.15 & 47.5 & 0.93 & 0.23 \\
\hline $\begin{array}{l}\text { Gas } \\
\text { oline } \\
2\end{array}$ & $\begin{array}{l}1,0 \\
00\end{array}$ & $\begin{array}{l}95 \\
\%\end{array}$ & 169 & $\begin{array}{l}46 \\
\%\end{array}$ & $\begin{array}{l}1.3 \\
0\end{array}$ & 194 & 535 & 64.5 & 0.33 & 0.32 & 75.2 & 0.39 & 0.37 \\
\hline $\begin{array}{l}\text { Gas } \\
\text { oline } \\
2\end{array}$ & $\begin{array}{l}1,0 \\
00\end{array}$ & $\begin{array}{l}75 \\
\%\end{array}$ & 137 & $\begin{array}{l}30 \\
\%\end{array}$ & $\begin{array}{l}1.8 \\
6\end{array}$ & 153 & 374 & 75.2 & 0.49 & 0.37 & 92.1 & 0.60 & 0.45 \\
\hline $\begin{array}{l}\text { Gas } \\
\text { oline } \\
2\end{array}$ & $\begin{array}{l}1,0 \\
00\end{array}$ & $\begin{array}{l}50 \\
\%\end{array}$ & 95 & $\begin{array}{l}14 \\
\%\end{array}$ & $\begin{array}{l}3.6 \\
1\end{array}$ & 102 & 193 & 97.3 & 0.95 & 0.48 & 102.2 & 1.00 & 0.50 \\
\hline $\begin{array}{l}\text { Gas } \\
\text { oline } \\
2\end{array}$ & $\begin{array}{l}1,0 \\
00\end{array}$ & $\begin{array}{l}25 \\
\%\end{array}$ & 58 & $5 \%$ & $\begin{array}{l}6.5 \\
3\end{array}$ & 51 & 107 & 51.0 & 1.00 & 0.25 & 51.0 & 1.00 & 0.25 \\
\hline
\end{tabular}




\begin{tabular}{|c|c|c|c|c|c|c|c|c|c|c|c|c|c|}
\hline $\begin{array}{l}\text { Gas } \\
\text { oline }\end{array}$ & $\begin{array}{l}2,0 \\
00\end{array}$ & $\begin{array}{l}95 \\
\%\end{array}$ & 168 & $\begin{array}{l}45 \\
\%\end{array}$ & $\begin{array}{l}1.3 \\
2\end{array}$ & 193 & 527 & 65.2 & 0.34 & 0.32 & 76.1 & 0.39 & 0.37 \\
\hline $\begin{array}{l}\text { Gas } \\
\text { oline } \\
2\end{array}$ & $\begin{array}{l}2,0 \\
00\end{array}$ & $\begin{array}{l}75 \\
\%\end{array}$ & 130 & $\begin{array}{l}27 \\
\%\end{array}$ & $\begin{array}{l}2.3 \\
2\end{array}$ & 153 & 300 & 92.8 & 0.60 & 0.45 & 115.2 & 0.75 & 0.56 \\
\hline $\begin{array}{l}\text { Gas } \\
\text { oline } \\
2\end{array}$ & $\begin{array}{l}2,0 \\
00\end{array}$ & $\begin{array}{l}50 \\
\%\end{array}$ & 86 & $\begin{array}{l}12 \\
\%\end{array}$ & $\begin{array}{l}5.4 \\
5\end{array}$ & 103 & 128 & 102.9 & 1.00 & 0.50 & 102.9 & 1.00 & 0.50 \\
\hline $\begin{array}{l}\text { Gas } \\
\text { oline } \\
2\end{array}$ & $\begin{array}{l}2,0 \\
00\end{array}$ & $\begin{array}{l}25 \\
\%\end{array}$ & 51 & $4 \%$ & $\begin{array}{l}10 . \\
67\end{array}$ & 51 & 65 & 51.03 & 1.00 & 0.25 & 51.03 & 1.00 & 0.25 \\
\hline
\end{tabular}

Table 5. Vapour generation for pipeline puncture scenarios, estimated using PHAST. Release rate is the total liquid release rate before evaporation.

Juxtaposition of the fraction evaporated from Buncefield-type tank overfill events (Table 4) and pipeline puncture events (Table 5) are shown in Figure 2. For moderately volatile liquids such as hexane and winter gasoline, the worstcase pipeline puncture event appears to be a combination of hole size and pipeline back-pressure that leads to the release about 50 percent of the import rate. The amount of fuel vaporized then exceeds that of a worst-case tank overfill event by a factor two or more. Although smaller hole sizes lead to higher orifice back-pressures and more efficient spray evaporation, the release rate also lowers, leading to an overall decrease in the amount of fuel evaporated.

Table 6 presents the results of using PHAST and the more advanced property model in the PHAST-based Stand-Alone Model (SAM). Figure 3 presents results for winter grade gasoline evaporation (the two spray angle cases averaged). SAM predicts less evaporation than PHAST but still significantly more than the baseline tank overfill scenario.

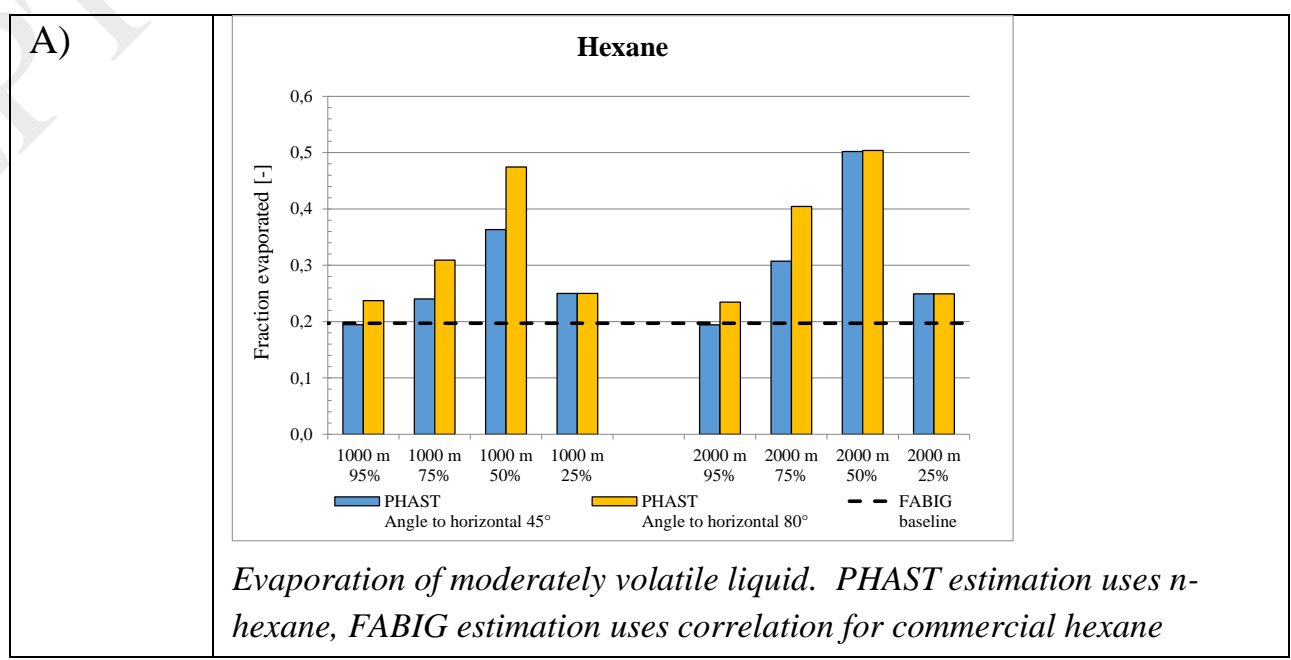




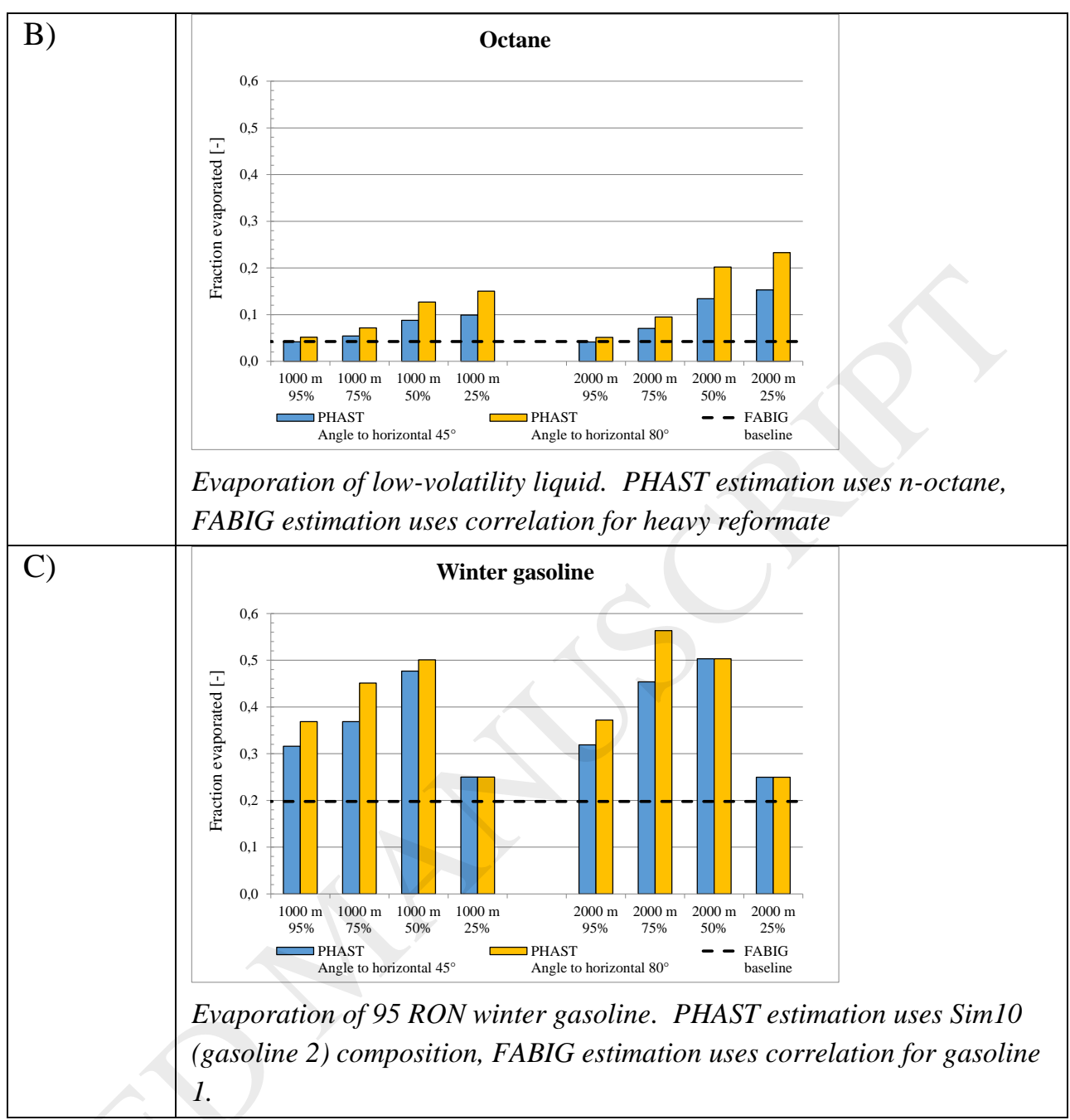

Figure 2. Evaporation following pipeline puncture event due to spray effects estimated using PHAST (vertical bars) compared with evaporation for Buncefield-type tank overfill event estimated using FABIG correlations (horizontal line). Evaporation is expressed as fraction of import rate.

Table 6. $\quad$ Effects of choice of model for computing thermodynamic properties of mixtures on evaporation. Comparison of the simple model in PHAST and the advanced PHAST-based Stand-Alone Model (SAM)

\begin{tabular}{|c|c|c|c|c|c|c|c|c|c|c|c|c|c|c|}
\hline \multirow{3}{*}{$\begin{array}{l}\text { Subst } \\
\text { ance }\end{array}$} & \multirow{3}{*}{$\begin{array}{l}\text { Pipe } \\
\text { line } \\
\text { leng } \\
\text { th } \\
{[\mathrm{m}]}\end{array}$} & \multirow{3}{*}{$\begin{array}{l}\text { Lea } \\
\mathrm{k} \\
(\% \\
\text { imp } \\
\text { ort } \\
\text { rate } \\
)\end{array}$} & & & & & \multicolumn{4}{|c|}{ Angle to horizontal $45^{\circ}$} & \multicolumn{4}{|c|}{ Angle to horizontal $80^{\circ}$} \\
\hline & & & \multicolumn{2}{|c|}{$\begin{array}{l}\text { Release } \\
\text { rate }[\mathrm{kg} / \mathrm{s}]\end{array}$} & \multicolumn{2}{|c|}{$\begin{array}{l}\text { Initial } \\
\text { droplet } \\
\text { diameter } \\
{[\mu \mathrm{m}]} \\
\end{array}$} & \multicolumn{2}{|c|}{$\begin{array}{l}\text { Evaporatio } \\
\mathrm{n} \text { rate } \\
{[\mathrm{kg} / \mathrm{s}]}\end{array}$} & \multicolumn{2}{|c|}{$\begin{array}{l}\text { Fraction of } \\
\text { import rate } \\
\text { evaporated } \\
{[-]}\end{array}$} & \multicolumn{2}{|c|}{$\begin{array}{l}\text { Evaporatio } \\
\mathrm{n} \text { rate } \\
{[\mathrm{kg} / \mathrm{s}]}\end{array}$} & \multicolumn{2}{|c|}{$\begin{array}{l}\text { Fraction of } \\
\text { import rate } \\
\text { evaporated } \\
{[-]}\end{array}$} \\
\hline & & & $\begin{array}{l}\mathrm{PH} \\
\mathrm{AS} \\
\mathrm{T} \\
\end{array}$ & $\begin{array}{l}\text { SA } \\
\mathrm{M}\end{array}$ & $\begin{array}{l}\mathrm{PH} \\
\mathrm{AS} \\
\mathrm{T} \\
\end{array}$ & $\begin{array}{l}\text { SA } \\
\mathrm{M}\end{array}$ & $\begin{array}{l}\mathrm{PH} \\
\mathrm{AS} \\
\mathrm{T} \\
\end{array}$ & $\begin{array}{l}\text { SA } \\
\text { M }\end{array}$ & $\begin{array}{l}\mathrm{PH} \\
\mathrm{AS} \\
\mathrm{T} \\
\end{array}$ & $\begin{array}{l}\text { SA } \\
\mathrm{M}\end{array}$ & $\begin{array}{l}\mathrm{PH} \\
\mathrm{AS} \\
\mathrm{T} \\
\end{array}$ & $\begin{array}{l}\text { SA } \\
\mathrm{M}\end{array}$ & $\begin{array}{l}\mathrm{PH} \\
\mathrm{AS} \\
\mathrm{T} \\
\end{array}$ & $\begin{array}{l}\text { SA } \\
\mathrm{M}\end{array}$ \\
\hline $\begin{array}{l}\text { n- } \\
\text { hexan } \\
\text { e }\end{array}$ & $\begin{array}{l}1,00 \\
0\end{array}$ & $\begin{array}{l}95 \\
\%\end{array}$ & 179 & 178 & 461 & $\begin{array}{l}48 \\
5\end{array}$ & 36.5 & $\begin{array}{l}36 . \\
8\end{array}$ & 0.19 & $\begin{array}{l}0.2 \\
0\end{array}$ & 44.5 & $\begin{array}{l}45 . \\
9\end{array}$ & 0.24 & $\begin{array}{l}0.2 \\
5\end{array}$ \\
\hline $\begin{array}{l}\text { n- } \\
\text { hexan } \\
\text { e }\end{array}$ & $\begin{array}{l}1,00 \\
0\end{array}$ & $\begin{array}{l}75 \\
\%\end{array}$ & 140 & 139 & 323 & $\begin{array}{l}34 \\
5\end{array}$ & 45.1 & $\begin{array}{l}45 . \\
2\end{array}$ & 0.24 & $\begin{array}{l}0.2 \\
4\end{array}$ & 58.0 & $\begin{array}{l}58 . \\
1\end{array}$ & 0.31 & $\begin{array}{l}0.3 \\
1\end{array}$ \\
\hline
\end{tabular}




\begin{tabular}{|c|c|c|c|c|c|c|c|c|c|c|c|c|c|c|}
\hline $\begin{array}{l}\text { n- } \\
\text { hexan } \\
\text { e }\end{array}$ & $\begin{array}{l}1,00 \\
0\end{array}$ & $\begin{array}{l}50 \\
\%\end{array}$ & 94 & 92 & 166 & $\begin{array}{l}18 \\
1\end{array}$ & 68.2 & $\begin{array}{l}67 . \\
0\end{array}$ & 0.36 & $\begin{array}{l}0.3 \\
6\end{array}$ & 89.0 & $\begin{array}{l}92 . \\
3\end{array}$ & 0.47 & $\begin{array}{l}0.5 \\
0\end{array}$ \\
\hline $\begin{array}{l}\text { n- } \\
\text { hexan } \\
\text { ex }\end{array}$ & $\begin{array}{l}1,00 \\
0\end{array}$ & $\begin{array}{l}25 \\
\%\end{array}$ & 47 & 46 & 92 & $\begin{array}{l}10 \\
1\end{array}$ & 46.9 & $\begin{array}{l}33 . \\
9\end{array}$ & 0.25 & $\begin{array}{l}0.1 \\
8\end{array}$ & 46.9 & $\begin{array}{l}42 . \\
6\end{array}$ & 0.25 & $\begin{array}{l}0.2 \\
3\end{array}$ \\
\hline $\begin{array}{l}\text { n- } \\
\text { hexan } \\
\text { e }\end{array}$ & $\begin{array}{l}2,00 \\
0\end{array}$ & $\begin{array}{l}95 \\
\%\end{array}$ & 177 & 177 & 457 & $\begin{array}{l}48 \\
1\end{array}$ & 36.5 & $\begin{array}{l}36 . \\
1\end{array}$ & 0.19 & $\begin{array}{l}0.2 \\
0\end{array}$ & 44.0 & $\begin{array}{l}45 . \\
1\end{array}$ & 0.23 & $\begin{array}{l}0.2 \\
4\end{array}$ \\
\hline $\begin{array}{l}\text { n- } \\
\text { hexan } \\
\text { e }\end{array}$ & $\begin{array}{l}2,00 \\
0\end{array}$ & $\begin{array}{l}75 \\
\%\end{array}$ & 141 & 139 & 259 & $\begin{array}{l}28 \\
0\end{array}$ & 57.7 & $\begin{array}{l}56 . \\
9\end{array}$ & 0.31 & $\begin{array}{l}0.3 \\
1\end{array}$ & 75.9 & $\begin{array}{l}74 . \\
4\end{array}$ & 0.40 & $\begin{array}{l}0.4 \\
0\end{array}$ \\
\hline $\begin{array}{l}\text { n- } \\
\text { hexan } \\
\text { e }\end{array}$ & $\begin{array}{l}2,00 \\
0\end{array}$ & $\begin{array}{l}50 \\
\%\end{array}$ & 95 & 92 & 110 & $\begin{array}{l}12 \\
1\end{array}$ & 94.2 & $\begin{array}{l}83 . \\
3\end{array}$ & 0.50 & $\begin{array}{l}0.4 \\
5\end{array}$ & 94.6 & $\begin{array}{l}92 . \\
5\end{array}$ & 0.50 & $\begin{array}{l}0.5 \\
0\end{array}$ \\
\hline $\begin{array}{l}\text { n- } \\
\text { hexan } \\
\text { e }\end{array}$ & $\begin{array}{l}2,00 \\
0\end{array}$ & $\begin{array}{l}25 \\
\%\end{array}$ & 47 & 45 & 56 & 63 & 46.8 & $\begin{array}{l}45 . \\
4\end{array}$ & 0.25 & $\begin{array}{l}0.2 \\
5 \\
\end{array}$ & 46.8 & $\begin{array}{l}45 . \\
4\end{array}$ & 0.25 & $\begin{array}{l}0.2 \\
5\end{array}$ \\
\hline $\begin{array}{l}\text { n- } \\
\text { octan } \\
e^{-}\end{array}$ & $\begin{array}{l}1,00 \\
0\end{array}$ & $\begin{array}{l}95 \\
\%\end{array}$ & 194 & 190 & 516 & $\begin{array}{l}56 \\
3\end{array}$ & 8.5 & 4.3 & 0.04 & $\begin{array}{l}0.0 \\
2\end{array}$ & 10.5 & 6.3 & 0.05 & $\begin{array}{l}0.0 \\
3\end{array}$ \\
\hline $\begin{array}{l}\text { n- } \\
\text { octan } \\
\text { e }\end{array}$ & $\begin{array}{l}1,00 \\
0\end{array}$ & $\begin{array}{l}75 \\
\%\end{array}$ & 152 & 148 & 362 & $\begin{array}{l}40 \\
2\end{array}$ & 11.1 & 6.7 & 0.05 & $\begin{array}{l}0.0 \\
3\end{array}$ & 14.6 & 9.5 & 0.07 & $\begin{array}{l}0.0 \\
5\end{array}$ \\
\hline $\begin{array}{l}\text { n- } \\
\text { octan } \\
\text { e }\end{array}$ & $\begin{array}{l}1,00 \\
0\end{array}$ & $\begin{array}{l}50 \\
\%\end{array}$ & 102 & 98 & 186 & $\begin{array}{l}21 \\
1\end{array}$ & 17.9 & $\begin{array}{l}15 . \\
5\end{array}$ & 0.09 & $\begin{array}{l}0.0 \\
8\end{array}$ & 25.9 & $\begin{array}{l}18 . \\
8\end{array}$ & 0.13 & $\begin{array}{l}0.1 \\
0\end{array}$ \\
\hline $\begin{array}{l}n- \\
\text { octan } \\
\text { e }\end{array}$ & $\begin{array}{l}1,00 \\
0\end{array}$ & $\begin{array}{l}25 \\
\%\end{array}$ & 51 & 49 & 103 & $\begin{array}{l}11 \\
8\end{array}$ & 20.2 & $\begin{array}{l}20 . \\
2\end{array}$ & 0.10 & $\begin{array}{l}0.1 \\
0\end{array}$ & 30.7 & $\begin{array}{l}21 . \\
9\end{array}$ & 0.15 & $\begin{array}{l}0.1 \\
1\end{array}$ \\
\hline $\begin{array}{l}\text { n- } \\
\text { octan } \\
\text { e }\end{array}$ & $\begin{array}{l}2,00 \\
0\end{array}$ & $\begin{array}{l}95 \\
\%\end{array}$ & 193 & 189 & 512 & $\begin{array}{l}55 \\
9\end{array}$ & 8.5 & 5.7 & 0.04 & $\begin{array}{l}0.0 \\
3\end{array}$ & 10.5 & 7.1 & 0.05 & $\begin{array}{l}0.0 \\
4\end{array}$ \\
\hline $\begin{array}{l}\text { n- } \\
\text { octan } \\
e^{-}\end{array}$ & $\begin{array}{l}2,00 \\
0\end{array}$ & $\begin{array}{l}75 \\
\%\end{array}$ & 153 & 148 & 290 & $\begin{array}{l}32 \\
4\end{array}$ & 14.4 & $\begin{array}{l}12 . \\
7\end{array}$ & 0.07 & $\begin{array}{l}0.0 \\
6\end{array}$ & 19.4 & $\begin{array}{l}15 . \\
8\end{array}$ & 0.10 & $\begin{array}{l}0.0 \\
8\end{array}$ \\
\hline $\begin{array}{l}\text { n- } \\
\text { octan } \\
\text { e }\end{array}$ & $\begin{array}{l}2,00 \\
0\end{array}$ & $\begin{array}{l}50 \\
\%\end{array}$ & 103 & 99 & 124 & $\begin{array}{l}14 \\
1\end{array}$ & 27.4 & $\begin{array}{l}30 . \\
2\end{array}$ & 0.13 & $\begin{array}{l}0.1 \\
5\end{array}$ & 41.2 & $\begin{array}{l}33 . \\
6\end{array}$ & 0.20 & $\begin{array}{l}0.1 \\
7\end{array}$ \\
\hline $\begin{array}{l}\mathrm{n}- \\
\text { octan } \\
\mathrm{e}\end{array}$ & $\begin{array}{l}2,00 \\
0\end{array}$ & $\begin{array}{l}25 \\
\%\end{array}$ & 51 & 47 & 63 & 30 & 31.2 & $\begin{array}{l}42 . \\
1\end{array}$ & 0.15 & $\begin{array}{l}0.2 \\
2\end{array}$ & 47.5 & $\begin{array}{l}47 . \\
3\end{array}$ & 0.23 & $\begin{array}{l}0.2 \\
4\end{array}$ \\
\hline $\begin{array}{l}\text { Gasol } \\
\text { ine } 2\end{array}$ & $\begin{array}{l}1,00 \\
0\end{array}$ & $\begin{array}{l}95 \\
\%\end{array}$ & 194 & 186 & 535 & $\begin{array}{l}56 \\
3\end{array}$ & 64.5 & $\begin{array}{l}41 . \\
4\end{array}$ & 0.32 & $\begin{array}{l}0.2 \\
1\end{array}$ & 75.2 & $\begin{array}{l}66 . \\
7\end{array}$ & 0.37 & $\begin{array}{l}0.3 \\
4\end{array}$ \\
\hline $\begin{array}{l}\text { Gasol } \\
\text { ine } 2\end{array}$ & $\begin{array}{l}1,00 \\
0\end{array}$ & $\begin{array}{l}75 \\
\%\end{array}$ & 153 & 147 & 374 & $\begin{array}{l}41 \\
2\end{array}$ & 75.2 & $\begin{array}{l}48 . \\
5\end{array}$ & 0.37 & $\begin{array}{l}0.2 \\
5\end{array}$ & 92.1 & $\begin{array}{l}60 . \\
6\end{array}$ & 0.45 & $\begin{array}{l}0.3 \\
1\end{array}$ \\
\hline $\begin{array}{l}\text { Gasol } \\
\text { ine } 2\end{array}$ & $\begin{array}{l}1,00 \\
0\end{array}$ & $\begin{array}{l}50 \\
\%\end{array}$ & 102 & 98 & 193 & $\begin{array}{l}21 \\
6\end{array}$ & 97.3 & $\begin{array}{l}91 . \\
8\end{array}$ & 0.48 & $\begin{array}{l}0.4 \\
7\end{array}$ & $\begin{array}{l}102 . \\
2\end{array}$ & $\begin{array}{l}71 . \\
3\end{array}$ & 0.50 & $\begin{array}{l}0.3 \\
6\end{array}$ \\
\hline $\begin{array}{l}\text { Gasol } \\
\text { ine } 2\end{array}$ & $\begin{array}{l}1,00 \\
0\end{array}$ & $\begin{array}{l}25 \\
\%\end{array}$ & 51 & 49 & 107 & $\begin{array}{l}12 \\
1\end{array}$ & 51.0 & $\begin{array}{l}48 . \\
7\end{array}$ & 0.25 & $\begin{array}{l}0.2 \\
5\end{array}$ & 51.0 & $\begin{array}{l}48 . \\
7\end{array}$ & 0.25 & $\begin{array}{l}0.2 \\
5\end{array}$ \\
\hline $\begin{array}{l}\text { Gasol } \\
\text { ine } 2\end{array}$ & $\begin{array}{l}2,00 \\
0\end{array}$ & $\begin{array}{l}95 \\
\%\end{array}$ & 193 & 185 & 527 & $\begin{array}{l}55 \\
4\end{array}$ & 65.2 & $\begin{array}{l}45 . \\
2\end{array}$ & 0.32 & $\begin{array}{l}0.2 \\
3\end{array}$ & 76.1 & $\begin{array}{l}70 . \\
3\end{array}$ & 0.37 & $\begin{array}{l}0.3 \\
6\end{array}$ \\
\hline $\begin{array}{l}\text { Gasol } \\
\text { ine } 2\end{array}$ & $\begin{array}{l}2,00 \\
0\end{array}$ & $\begin{array}{l}75 \\
\%\end{array}$ & 153 & 150 & 300 & $\begin{array}{l}31 \\
1\end{array}$ & 92.8 & $\begin{array}{l}73 . \\
6\end{array}$ & 0.45 & $\begin{array}{l}0.3 \\
7\end{array}$ & $\begin{array}{l}115 . \\
2\end{array}$ & $\begin{array}{l}10 \\
6.3\end{array}$ & 0.56 & $\begin{array}{l}0.5 \\
4\end{array}$ \\
\hline $\begin{array}{l}\text { Gasol } \\
\text { ine } 2\end{array}$ & $\begin{array}{l}2,00 \\
0\end{array}$ & $\begin{array}{l}50 \\
\%\end{array}$ & 103 & 98 & 128 & $\begin{array}{l}14 \\
4\end{array}$ & $\begin{array}{l}102 . \\
9\end{array}$ & $\begin{array}{l}98 . \\
3\end{array}$ & 0.50 & $\begin{array}{l}0.5 \\
0\end{array}$ & $\begin{array}{l}102 . \\
9\end{array}$ & $\begin{array}{l}73 . \\
2\end{array}$ & 0.50 & $\begin{array}{l}0.3 \\
7\end{array}$ \\
\hline $\begin{array}{l}\text { Gasol } \\
\text { ine } 2\end{array}$ & $\begin{array}{l}2,00 \\
0\end{array}$ & $\begin{array}{l}25 \\
\%\end{array}$ & 51 & 49 & 65 & 74 & 51.0 & $\begin{array}{l}48 . \\
6\end{array}$ & 0.25 & $\begin{array}{l}0.2 \\
5\end{array}$ & 51.0 & $\begin{array}{l}48 . \\
6\end{array}$ & 0.25 & $\begin{array}{l}0.2 \\
5\end{array}$ \\
\hline
\end{tabular}




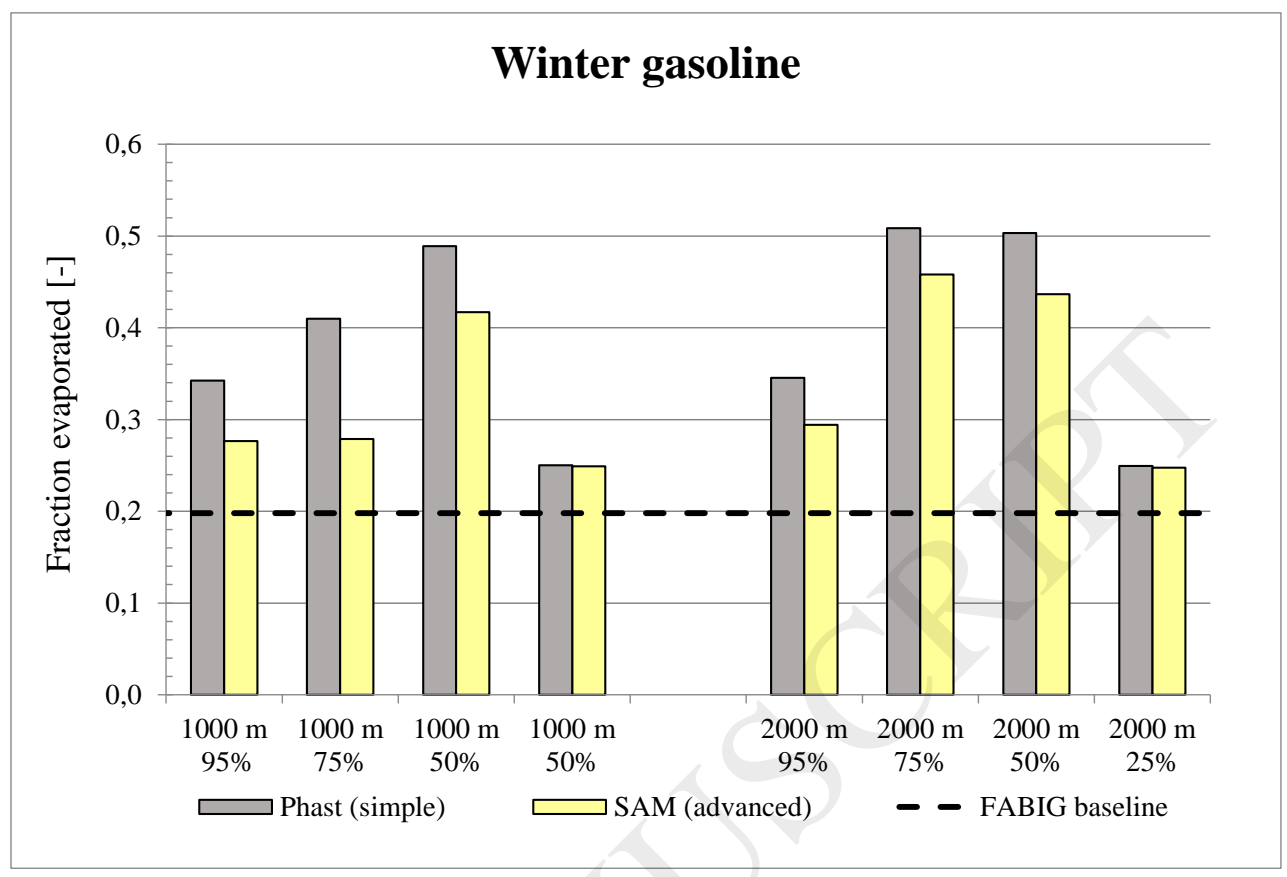

Figure 3. Evaporation of winter gasoline for pipeline puncture scenarios. Improved thermodynamic modelling of mixtures (SAM) predicts less evaporation than PHAST but still much more than the baseline tank overfill scenario (FABIG). Evaporation is expressed as fraction of import rate. 


\section{Discussion}

\subsection{Early work}

In risk consultancy work of a fuel depot in 2008, COWI reported (confidential and unpublished) that PHAST output suggested that spray evaporation following pipeline puncture could produce very large vapour clouds. The implications were not fully realized however, as generally accepted models of evaporation from tank overfill events were not available and overfill events were generally believed to be the worst-case scenario.

In 2016, the issue resurfaced (confidential and unpublished), in part because an import pipeline to a fuel depot was severely deformed when the raised crane of a passing truck struck a pipeline road overpass. Hazard analysis using PHAST clearly showed that major pipeline damage produced the largest hazard range of all the loss of containment scenarios considered for the fuel depot. Key inputs to some models were approaching the limits of the recommended range of application however, in particular low orifice back-pressures. An additional concern was that the findings, while technically defensible and correct, might be an artefact of PHAST's simplified modelling of properties of wide-range multi-component mixtures. Although the software developer did not advice against the computational procedure, doubts remained. Those doubts eventually led to this work.

\subsection{Improved thermodynamic modelling}

The work reported here largely supports those doubts. Advanced thermodynamic modelling indicates that PHAST does overestimate evaporation from spray releases of mixtures. The main finding stands however: Modelling shows that spray evaporation following puncture of an import gasoline pipeline can evaporate large quantities of fuel, perhaps exceeding the evaporation from a Buncefield-type tank overfill event by a factor two or more.

There are many challenges associated with extracting a single stand-alone model from a suite of integrated models. PHAST modelling of the behavior of airborne droplet in a moving mass of entrained air takes place in the complex UDM module, not the spray module. Stand-alone modelling of the UDM module is outside the scope of this project however, and the issue was managed though model tuning, details are provided in the appendix. As a result, we can only state that PHAST likely overestimates spray evaporation for wide-range multicomponent mixtures. We cannot state how much.

\subsection{Mixing with air}

The main concern in hazard analysis of fuel depots is a loss of containment event leading to an Open Flammable Cloud Explosion (OFCE). An OFCE has three principal characteristics: 1) A release of a large quantity of flammable vapour. 2) Good mixing with air to produce a large volume within the 
flammability limits, since rapid flame propagation and blast effects will only occur through those premixed explosive regions. Moreover, there must 3) be a delay, of undefined duration, before ignition, to build up a large cloud [2]. Calm conditions represent a worst case [23], [33], [34]

This paper only considers the first step, the quantity evaporated. It has been argued however, that good mixing with air may be the critical step in OFCE hazard analysis [2]. The cascade and splash evaporation at Buncefield likely led to near-optimal (stoichiometric) mixing [14].

More research is needed to determine whether spray and fountain evaporation from a puncture event will also lead to near- stoichiometric mixing with air. We hypothesize however, that the freefall stage of a fountain release may indeed be comparable to a cascade release. We find it noteworthy that the authors of a recent review of past large vapour cloud explosions conclude that "smaller" vapour release rates, a term the authors reserve to rates lower than $100 \mathrm{~kg} / \mathrm{s}$, i.e. similar to those considered in this paper, seem to have a propensity to produce an OFCE rather than a flash fire [33].

\subsection{Re-appraisal of the hazard potential of fuel depots}

As stated in the introduction, the Buncefield explosion in 2005 fundamentally changed the perceived hazard potential of gasoline fuel depots. Immediately following the accident, the Buncefield Major Incident Investigation Board accepted what appeared to be the view commonly held by the industry and the relevant expert community in Britain: that this was an unprecedented event [2].

Failures should be valued as unique learning opportunities. Evidently, it makes good sense to share the lessons learned from unwanted outcomes in order to minimize the number of times the same lessons have to be learned [35]. It is therefore remarkable that a number of overfill-related gasoline vapour cloud explosions had occurred on earlier occasions, e.g. Houston, TX, USA, 1962; Baytown, TX, USA, 1977; California, USA, 1981; Newark, NJ, USA, 1983; Naples, Italy, 1985; and Sri Racha, Laem Chabang, Thailand, 1999 [1], [4], [6], [36], [37]. Some 20 years before Buncefield, authors had discussed the hazard potential [38]. In this light, the Buncefield incident may well stand out as exceptional, not that it took place, but that it was thoroughly studied and lessons shared.

Johnson reflects on whether the Buncefield incident was foreseeable. The answer is largely affirmative: All the elements of the incident were recognised as being possible [6]. Mannan arrives at a similar conclusion: There was nothing new or unforeseeable about what happened at Buncefield [36], [39]. Despite availability of evidence, there was limited appreciation of the hazard.

An analogous situation may currently exist for spray releases following pipeline puncture. Previous incidents have taken place. In Saint Herblain, France, 1991, a release of gasoline from a transfer pipe inside a bund produced a vapour cloud which upon ignition produced extensive explosion damage [40]. At a terminal in Jaipur, India, 2009, a large leak occurred from a valve on a 
tank outlet. The leak resulted in a fountain or spray of gasoline directed upwards from the valve driven by the hydrostatic pressure in the tank only, i.e. a very modest overpressure. The leak produced a very large cloud which exploded with devastating force [41].

Other pipeline incidents with extensive evaporation of gasoline appear to have taken place elsewhere. An anonymous reviewer pointed to four incidents in USA: Bellingham (WA) on 10 June 1999, Allentown (PA) on 1 February 2005, Pasadena (TX) on 23 September 2008 and Colon (MO) on 5 December 2008. Available information is sparse however. In the Bellingham case, for example, the official investigation [42] merely provides sporadic mention of a large vapour cloud travelling down a creek: A young man fishing was overcome by hydrocarbon fumes, lost consciousness and drowned; a resident reported that odours were overwhelming and his dog was convulsing, but the investigation does not mention an explosion upon ignition, only fire. Another source [43] says that vapour clouds were reported visible to 10 feet over city streets, probably in downtown Bellingham, well over a mile from the rupture location, and provides vague reference to a "bomb-like blast" at the rupture location. More work is necessary to evaluate the relevance and significance of these incidents.

More recently, authors [14], [23] have argued that many of the physical processes that apply in a spray release are common with the overfilling problem. Yet, there appears to be limited appreciation of the spray evaporation hazard.

\subsection{Future research}

Before Buncefield, only the release of superheated liquids (e.g. propane and butane) were thought to be capable of producing large vapour clouds [2], [5]. Early spray modelling work is largely concerned with releases of flashing liquids, e.g. [25], [44]. The literature on spray releases of moderately volatile liquids appears sparse.

An experimental study on rainout data for spray releases of non-flashing water and xylene [21] showed that droplet behaviour in the jet is more complex than PHAST assumes. The spray is initially dominated by a small number of large non-spherical droplets that undergo secondary break-up further downstream the nozzle. Another experimental study [22] suggested that that the current UDM model implemented in PHAST under-predicts the droplet size, in particular for gasoline releases. The prediction of an overly small initial droplet size will tend to produce too much evaporation, although droplets will subsequently reduce in size due to secondary droplet breakup and so the net effect of the model's poor prediction of the initial droplet size may be limited. More research is clearly needed.

A better understanding of the effects of the different input parameters to the estimation procedure is needed. A detailed sensitivity and uncertainty analysis using global methods such as variance based decomposition techniques [45], [46] and Monte Carlo techniques [47] will help quantify the contribution of the 
inputs to predicted evaporation rates. Commercial gasoline is manufactured to meet engine requirements and its exact chemical composition is inherently illdefined and variable. This should also be accounted for in sensitivity analysis.

Above all, however, future research should rectify the scarcity of large-scale experimental data for spray releases of moderately-volatile liquids to aid model verification. 


\section{Conclusion}

Hazard analysis using PHAST predicts that extensive evaporation will take place due to spray and fountain effects following a pipeline puncture. To evaluate the significance of the spray release mechanism in hazard analysis of fuel depots, the quantity evaporated is compared against the quantity evaporated in a Buncefield type overfill event, which is currently considered to be the worst-case event for fuel depots.

This paper examines releases of two pure substances and a mixture: Moderately volatile hexane, low-volatility octane and winter gasoline. PHAST modelling consistently shows that a spray release can evaporate more fuel than an overfill event, in particular for gasoline, the substance of key interest to this paper due to the ubiquity of gasoline storage sites in society.

Proper modelling of evaporation of wide-range multi-component mixtures such as gasoline is challenging. For calculation of thermodynamic properties, PHAST represents the mixture with a pseudo-pure component, a simplification which may introduce errors. We develop a stand-alone spray model with advanced thermodynamic capability. Results suggest that PHAST does overestimate evaporation of mixtures. Still, this paper finds that evaporation following pipeline puncture may exceed the evaporation from a Buncefieldtype tank overfill event by a factor two or more. The finding may lead to a reappraisal of the hazard potential of pipelines and fuel depots.

This leads to the overall conclusion that pipeline punctures may be the worstcase scenario in hazard analysis of fuel depots. This is a novel proposition, which runs counter to established hazard analysis practice. While the incident at Jaipur, India, may provide some empirical support for this proposition, more research is clearly necessary, in particular large-scale experimental work for model verification, before conclusions of a more confident nature can be stated. In the meantime, a cautious approach in hazard analysis would be to include scenarios with spray evaporation from pipeline punctures. 


\section{Software}

This study used Phast Risk (Version 8.0) from DNV GL software. MATLAB [28] was used for the PHAST-based model using an advanced multi-component mixture model. 


\section{Conflicts of interest}

The authors declare that they have no conflicts of interests 


\section{$9 \quad$ Contributorship}

This paper uses the first-last-author-emphasis approach and lists other authors in the order of importance of their contributions. The main authors of this work are F. Hedlund and J. Frutiger. F. Hedlund generated the idea, designed and initiated the project, coordinated tasks and drafted the article. J. Frutiger developed the PHAST-based model with real mixture properties, carried out all MATLAB model computations, drafted parts of the article and wrote the appendix. J. Boier Pedersen defined accident scenarios and carried out all PHAST computations. G. Sin provided technical and academic overview and guidance. F. Garde and E. Kragh were first to identify the significance of the pipeline puncture scenario. All authors have revised and contributed significantly to the final version. 


\section{Acknowledgement}

This project was only possible with support from the COWI Foundation (Grant A-137.10). The contents of this paper including any opinions and/or conclusions expressed, are those of the authors alone and do not necessarily reflect the policy of their organizations. 


\section{Appendix A: Model for spray release evaporation from pipe damage}

A stand-alone model for spray release evaporation from pipeline puncture has been implemented in MATLAB [28]. The model is independent from but faithful to PHAST as the stand-alone model mimics the approach taken in PHAST and is based on the same theoretical foundation. The aim has been to provide an as faithful representation of the PHAST model as possible, within the time and budget constraints of this project. The stand-alone model is then enhanced with advanced thermodynamic modelling capability for mixtures, a capability PHAST has not. The purpose is to examine the effect of improved thermodynamic modelling of mixtures on the estimated amount of evaporation for spray releases.

It is true that PHAST provides a multi-component version with advanced thermodynamic modeling. This version does not model rain-out however. The model retains droplets suspended in air until they are fully evaporated or the flammable concentration is below the cut-off concentration. The model is therefore not suitable for estimation of evaporation of moderately volatile liquids for which the rainout fraction is significant. The following scenario is considered: A gasoline pipe is ruptured forming an orifice. The liquid gasoline discharges and expands into the atmosphere, forming a stream of droplets, where gasoline evaporates and forms a vapour cloud. The stream of droplets subsequently touches the ground and forms a pool.

The model consists of 3 parts:

1) A discharge due to rupture

2) Droplet formation

3) Droplet evaporation

\section{Input specification}

The model can be solved through the following input specification.

Static pressure and temperature of the gasoline pipe: $\mathrm{P}_{\mathrm{st}}$ and $\mathrm{T}_{\mathrm{st}}$

Orifice (hole) diameter: $d_{\text {hole }}$

Average droplet trajectory angle: $\theta$

Atmospheric pressure and temperature: $\mathrm{P}_{\mathrm{a}}$ and $\mathrm{T}_{\mathrm{a}}$

Furthermore, the following gasoline properties need to be calculated through a suitable equation of state [29] or obtained from a tabulated database [48], [49]. 
These properties are dependent on temperature $\mathrm{T}$ and pressure $\mathrm{P}$.

Vapour phase pressure: $\mathrm{P}(\mathrm{T})$

Liquid and vapour density: $\rho_{\mathrm{l}}(\mathrm{T}, \mathrm{P})$ and $\rho_{\mathrm{v}}(\mathrm{T}, \mathrm{P})$

Liquid and vapour enthalpy: $h_{1}(T, P)$ and $h_{v}(T, P)$

Liquid and vapour entropy: $\mathrm{s}_{\mathrm{l}}(\mathrm{T}, \mathrm{P})$ and $\mathrm{s}_{\mathrm{v}}(\mathrm{T}, \mathrm{P})$

Liquid phase and vapour phase heat capacity: $\mathrm{Cp}_{1}(\mathrm{~T}$,$) and \mathrm{Cp}_{\mathrm{v}}(\mathrm{T}, \mathrm{P})$

\section{Discharge due to pipe rupture}

When a gasoline pipes ruptures, the pressurized liquid is discharged and expanded through the orifice into the atmosphere. The equations are based on the books of Street at al. on elementary fluid mechanics [50] and Mannan et al. on liquid discharge and loss prevention [51]. The model is based on the following assumptions:

The gasoline flow is in complete liquid state at the orifice.

There are negligible pressure and temperature effects at the orifice.

The velocity at the orifice $\mathrm{u}_{0}$ is given by Bernoulli's equation for incompressible fluids

$$
u_{0}=\sqrt{2 \frac{P_{\mathrm{st}}-P_{\mathrm{a}}}{\rho_{\mathrm{lst}}\left(T_{\mathrm{st}}, P_{\mathrm{st}}\right)}}
$$

where $\mathrm{P}_{\mathrm{st}}$ is the static gasoline back-pressure in the pipe, $\mathrm{P}_{\mathrm{a}}$ is the atmospheric pressure, $\rho_{\mathrm{lst}}$ is the liquid density of gasoline at the static pipe pressure $\mathrm{P}_{\mathrm{st}}$ and temperature $\mathrm{T}_{\mathrm{st}}$. The orifice temperature $\mathrm{T}_{0}$ and pressure $\mathrm{P}_{0}$ is set equal to the atmospheric conditions, $\mathrm{P}_{\mathrm{a}}$ and $\mathrm{T}_{\mathrm{a}}$ :

$$
\begin{aligned}
& P_{0}=P_{\mathrm{a}} \\
& T_{0}=T_{\mathrm{a}}
\end{aligned}
$$

The orifice mass flux $\mathrm{G}_{0}$ is given then by

$$
G_{0}=\frac{u_{0}}{v_{0}}
$$




$$
v_{0}=\frac{1}{\rho_{10}\left(T_{0}, P_{0}\right)}
$$

with $\mathrm{v}_{0}$ being the specific volume $\rho_{10}$ the liquid density at the orifice. The frictional effect of convergent flow at the orifice reduces the overall mass flow rate. The reduction is expressed through the discharge coefficient $C_{D}$. Here, it is assumed $C_{D}=0.6$. The overall release mass flow $Q$ through the orifice is calculated using the orifice cross-sectional area $\mathrm{A}_{0}$ through

$$
\begin{aligned}
& Q=C_{D} A_{0} G_{0} \\
& A_{0}=\left(\frac{d_{\text {hole }}}{2}\right)^{2} \pi
\end{aligned}
$$

After the orifice the gasoline fluid expands into the atmosphere. The final velocity in the atmosphere is given by the following momentum balance:

$$
\begin{aligned}
& G_{0}=\frac{u_{0}}{v_{0}} \\
& v_{0}=\frac{1}{\rho_{10}\left(T_{0}, P_{0}\right)}
\end{aligned}
$$

Due to negligible pressure effects at the orifice, there is no depressurisation assumed from the orifice pressure to the ambient pressure, hence no atmospheric expansion is calculated. This assumption is reasonable, because there are not large pressure and temperature differences between the pipe and the atmosphere and the gasoline is in liquid state.

\section{Droplet formation}

For an aerodynamic break-up mechanism, the mean droplet diameter $\mathrm{d}_{\mathrm{da}}$ can be calculated using the critical Weber number, which accounts for the liquid-air interface, shear forces and surface tension forces [25]:

$$
d_{\mathrm{da}}=\frac{\sigma_{\mathrm{L}} W e_{\text {crit }}}{u_{0}^{2} \rho_{\mathrm{a}}}
$$

where $\sigma_{\mathrm{L}}$ is the surface tension of gasoline, We $\mathrm{e}_{\text {crit }}$ the critical Weber number and $\rho_{\mathrm{a}}$ the atmospheric density. Following the guidelines of Brown et al. [52], it is assumed that $\mathrm{We}_{\text {crit }}=12$ for low-viscosity fluids. Assuming spherical droplets, the initial droplet mass can be written as 


$$
m_{\mathrm{d} 0}=\rho\left(T_{\mathrm{st}}, \mathrm{P}_{\mathrm{a}}\right) \frac{4 \pi}{3}\left(\frac{d_{\mathrm{da}}}{2}\right)^{3}
$$

The number of released droplets per second can then be obtained using the total release mass flow rate $\mathrm{Q}$ :

$$
N_{\mathrm{d}}=\frac{Q}{m_{\mathrm{d}}{ }^{0}}
$$

\section{Droplet evaporation}

The droplet evaporation model is based on the work of Woodward et al. [26]. We would like to explicitly refer to their work for more details on the fundamentals of the model equations.

No droplet size distribution is used. Hence, it is assumed that the larger evaporation due to larger droplets is compensated by the smaller evaporation of smaller droplets. Therefore, all the calculations are performed for an average droplet with an initial droplet diameter equal to the mean droplet diameter.

Woodward et al. [26] assumed the droplets surrounded by a mixture of air and gasoline vapour. In order to obtain the gasoline droplet mass and temperature as function of the distance to the orifice, a system of ordinary differential equations needs to be solved that includes a mass balance, an energy balance and a momentum balance. The change in droplet mass is obtained through the mass transfer equation (see Eq. (11)). The change in the droplet temperature is described using an energy balance taking into account the temperature change due to heat transfer and heat of evaporation (see Eq. (12). The momentum balance (Eq. (13)) accounts for the change in velocity $u_{d}$ :

$$
\begin{aligned}
& \frac{\mathrm{d} m_{\mathrm{d}}}{\mathrm{d} s}=-\frac{1}{u_{d}} A_{\mathrm{d}} K_{g} \rho\left(P_{\mathrm{a}}, T_{\mathrm{d}}\right) C^{\prime} \ln \left(\frac{1-y_{\mathrm{g}}}{1-\frac{y_{\mathrm{s}}}{T_{\mathrm{d}} / T_{\text {vap }}}}\right) \\
& \frac{\mathrm{d} T_{\mathrm{d}}}{\mathrm{d} s}=\frac{1}{u_{\mathrm{d}}} \frac{A_{\mathrm{d}} h\left(T_{\text {vap }}-T_{\mathrm{d}}\right)+u_{\mathrm{d}} \frac{\mathrm{d} m_{\mathrm{d}}}{\mathrm{d} s} h_{\mathrm{fg}}}{m_{\mathrm{d}} C_{\mathrm{pL}}} \\
& \frac{\mathrm{du}}{\mathrm{d} s}=\frac{1}{u_{\mathrm{d}} m_{\mathrm{d}}}\left(u_{\mathrm{d} z} u_{\mathrm{d}} \frac{\mathrm{d} m_{\mathrm{d}}}{\mathrm{d} s}+F_{\text {body }}+F_{\mathrm{drag}}\right)
\end{aligned}
$$


In Eq. (11) $m_{d}$ is the droplet mass, $s$ the distance from the orifice, $A_{d}$ the surface of the spherical droplet, $K_{\mathrm{g}}$ the overall mass transfer coefficient, $\rho$ the droplet density, C' the Stefan flow correction factor, $\mathrm{yg}_{\mathrm{g}}$ the mole fraction of gasoline in the vapour phase around the droplets, $y_{s}$ the equilibrium mole fraction of gasoline on the droplet surface, $T_{d}$ is the droplet temperature, and $\mathrm{T}_{\text {vap }}$ the vapour phase temperature of the vapour cloud surrounding the droplet. In Eq. (12) $h_{\mathrm{fg}}$ is the heat of evaporation, $\mathrm{h}$ the overall heat transfer coefficient, and $\mathrm{Cp}_{\mathrm{L}}$ the liquid heat capacity. In Eq. (13) $\mathrm{u}_{\mathrm{dz}}$ is the vertical components of droplet speed, $F_{\text {body }}$ the buoyancy force, $F_{\text {drag }}$ the drag force.

The system of system of ordinary differential equations is solved for the following initial conditions:

$$
\begin{aligned}
& m_{\mathrm{d}}(s=0)=m_{\mathrm{d} 0} \\
& T_{\mathrm{d}}(s=0)=T_{\mathrm{st}} \\
& T_{\text {vap }}(s=0)=T_{\mathrm{a}}
\end{aligned}
$$

Eq. (14) is the initial mass of the droplet derived from the volume of the spherical droplet using the mean droplet diameter. The integration of the differential equations is terminated when the droplets hits the ground, this is approximated using the equation for the projectile motion

$$
s_{\text {end }}=\frac{\left(u_{0}\right)^{2} \sin (\theta)}{2 g}
$$

where $\mathrm{g}$ is the gravitational constant and $\theta$ the average droplet's trajectory angle.

In each integration step of the system of ordinary differential equations the temperature, mass and velocity dependent variables and constants that occur in Eq. (11) to (12) need to be updated. In the following the auxiliary equations of these variables are presented that are solved in each iteration step. The following variables are all to be considered at position s, e.g. the surface area of a droplet at position $\mathrm{s}$ is written as $\mathrm{A}_{\mathrm{d}}(\mathrm{s})$.

The droplet surface area $A_{d}$ is obtained from the droplet mass $m_{d}$, through calculating the droplet density $\rho\left(T_{d}, P_{a}\right)$, radius $r_{d}$ and volume $V_{d}$.

$$
A_{\mathrm{d}}(s)=4 \pi\left(r_{\mathrm{d}}(s)\right)^{2}
$$




$$
\begin{aligned}
& r_{\mathrm{d}}(s)=\left(\frac{V_{\mathrm{d}}(s)}{4 / 3 \pi}\right)^{1 / 3} \\
& V_{\mathrm{d}}(s)=\frac{m_{\mathrm{d}}(s)}{\rho\left(T_{\mathrm{d}}, \mathrm{P}_{\mathrm{a}}\right)}
\end{aligned}
$$

The overall mass transfer coefficient $\mathrm{K}_{\mathrm{g}}$ can be calculated using the Sherwood number Sh and the diffusivity of the gasoline in air, $\mathrm{D}_{\mathrm{a}}$.

$$
K_{\mathrm{g}}=\frac{\operatorname{Sh} D_{\mathrm{a}}\left(T_{\mathrm{d}}\right)}{r_{\mathrm{d}}}
$$

The mean temperature $T_{m}$ is the difference between the evaporation temperature $T_{\text {vap }}$ and the temperature at the droplet surface $T_{d}$ :

$$
T_{\mathrm{m}}=\frac{T_{\mathrm{vap}}+T_{\mathrm{d}}}{2}
$$

The Sherwood Sh number is obtained through an empirical correlation of the Schmidt number Sc, the Reynolds number Re and the mass transfer number Bm:

$$
\begin{aligned}
& S h=\left(a+b R e^{1 / 2} S c^{1 / 2}\right) /\left(1+B_{\mathrm{m}}\right) \\
& S c=\frac{\mu_{\mathrm{a}}\left(T_{\mathrm{m}}\right)}{\rho_{\mathrm{a}} D_{\mathrm{a}}\left(T_{\mathrm{m}}\right)} \\
& B_{\mathrm{m}}=\frac{C_{\mathrm{pv}}\left(T_{\mathrm{m}}\right)\left(\mathrm{T}_{\mathrm{vap}}-\mathrm{T}_{\mathrm{d}}\right)}{h_{\mathrm{fg}}\left(T_{\mathrm{d}}\right)}
\end{aligned}
$$

The correlation parameters are set to be $a=1.03$ and $b=0.23$. $h_{f g}$ is the heat of vaporization, $\mathrm{Cp}_{\mathrm{v}}$ is the heat capacity of the gasoline vapour phase.

The correction constant $C^{\prime}$ is made up of two terms: 1) a term for Stefan flow which accounts for enhanced evaporation at high mass flux, and 2) a correction for the temperature gradient on the diffusion coefficient as described by Barrett and Clement [53], where $\mu=1.8$.

$$
C^{\prime}=\left[1+\frac{P_{v}\left(T_{m}\right)}{2 P_{a}}\right] \cdot\left[\frac{(2-\mu)\left(T_{\text {vap }}-T_{d}\right)}{T_{\text {vap }}^{(\mu-1)}\left(T_{\text {vap }}^{(2-\mu)}-T_{d}^{(2-\mu)}\right)}\right]
$$


The Reynolds number Re is found as follows

$$
R e=\frac{2 r_{\mathrm{d}}\left|u_{\mathrm{z}}-u_{\mathrm{dz}}\right| \rho_{\mathrm{cld}}}{\mu_{\mathrm{a}}\left(T_{\mathrm{m}}\right)}
$$

where $\left|\mathrm{u}_{\mathrm{z}}-\mathrm{u}_{\mathrm{dz}}\right|$ is the velocity difference between the cloud and the droplet, $\rho_{\mathrm{cld}}$ is the cloud density and cloud and $\mu_{\mathrm{a}}$ the dynamic viscocity of gasoline in air.

The drag force, $F_{\text {drag }}$, and the buoyancy force, $F_{\text {body }}$, are obtained as follows

$$
\begin{aligned}
& F_{\text {drag }}=\frac{1}{2} C_{\mathrm{Dd}} \rho_{\mathrm{cld}} \pi r_{\mathrm{d}}^{2}\left|\mathrm{u}_{z}-\mathrm{u}_{\mathrm{d} z}\right| \mathrm{u}_{z}-\mathrm{u}_{\mathrm{d} z} \mid \\
& F_{\text {body }}=\left(\rho_{\text {cld }}-\rho_{\mathrm{L}}\right) \mathrm{gV}_{\mathrm{d}}
\end{aligned}
$$

$\rho_{\mathrm{L}}$ is the liquid density of gasoline and $\mathrm{g}$ is the gravitational constant.

The drag coefficient $\mathrm{CD}_{\mathrm{d}}$ is depending on the Reynolds number:

$$
\begin{aligned}
& C_{\mathrm{Dd}}=0.44 \text { for } \operatorname{Re}>985 \\
& C_{\mathrm{Dd}}=24 \frac{1+0.15 \operatorname{Re}^{687}}{\operatorname{Re}} \text { for } 2<\operatorname{Re}<985 \\
& C_{\mathrm{Dd}}=24 \frac{1+\frac{3 \operatorname{Re}}{16}+\frac{9 \operatorname{Re}^{2} \log (2 R e)}{160}}{\operatorname{Re}} \text { for } 0.1<\operatorname{Re}<2 \\
& C_{\mathrm{Dd}}=24 / \operatorname{Re} \text { for } \operatorname{Re}<0.1
\end{aligned}
$$

The heat transfer coefficient is obtained from Nusselt $(\mathrm{Nu})$ and Prantl (Pr) number

$$
\begin{aligned}
& h=\frac{N u k\left(T_{\text {vap }}\right)}{r_{d}} \\
& N u=\frac{a+b \operatorname{Re}^{1 / 2} \operatorname{Pr}^{1 / 3}}{1+B_{\mathrm{m}}} \\
& \operatorname{Pr}=\frac{C_{\mathrm{pv}}\left(T_{\mathrm{m}}\right) \mu_{\mathrm{a}}\left(T_{\mathrm{m}}\right)}{k\left(T_{\mathrm{m}}\right)}
\end{aligned}
$$

where $\mathrm{k}$ is the heat conductivity of gasoline.

Modelling was challenging because some of PHAST's computations of energy balance and mechanical turbulent mixing with ambient air takes place in the Unified Dispersion Model (UDM) module of the software package, not in the 
spray module. Modelling of the UDM unit module is beyond the scope and budget of the present work however. The issue was managed through model tuning.

When leaving the orifice, a droplet is assumed to be surrounded by a sphere of air, which moves with the droplet. Boundary layer transport of energy and mass takes place between the droplet and the air in the sphere, but not between the sphere and the ambient air. Ideal mixing is assumed the sphere. The mass of air in the sphere is estimated through model tuning. We align the output of the Stand-Alone Model to that of PHAST for the pure component n-hexane. We separate the pure component results into a training set and a test set. The training set is used to determine the mass of air and the test set is used to compare and validate the assumed mass of air.

\section{Pool evaporation ignored}

Evaporation is only considered while the material is airborne as droplets in a dispersing jet/fountain, not in pool evaporation after it has rained-out on ground. Similarly, when computing evaporation from a Buncefield-type overfill event, we consider the contributions to evaporation from cascading falling liquid and splashing effects at the tank base only. They contribute more to the source term than diffusive evaporation from a pool [15]. The simplification has additional benefits. Because some of the lighter components evaporate while airborne in the spray/cascade phase, the composition of the material that enters the pool has changed. PHAST is unlikely to take this in account. The simplification also eliminates uncertainties related to how sensitive PHAST's pool evaporation model is to the representation of a mixture by a pseudo-pure component. A more practical argument for ignoring step 4 is to avoid that arbitrary assumptions about drainage and pool area near the pipeline puncture, and similar pool (tank yard) area assumptions for the overfilled tank, influence the comparative analysis. 


\section{References}

[1] BMIIB, "Buncefield Major Incident Investigation: Initial Report to the Health and Safety Commission and the Environment Agency of the investigation into the explosions and fires at the Buncefield oil storage and transfer depot, Hemel Hempstead, on 11 December 200," Buncefield Major Incident Investigation Board, London, U.K., 2006.

[2] BMIIB, "The Buncefield Incident 11 December 2005. The final report of the Major Incident Investigation Board," Buncefield Major Incident Investigation Board, London, U.K., 2008.

[3] BMIIB, "The Buncefield Investigation: Progress report," Buncefield Major Incident Investigation Board, London, U.K., 2006.

[4] M. Hailwood, M. Gawlowski, B. Schalau, and A. Schoenbucher, "Conclusions Drawn from the Buncefield and Naples Incidents Regarding the Utilization of Consequence Models," Chem. Eng. Technol., vol. 32, no. 2, pp. 207-231, 2009.

[5] I. Herbert, "The UK Buncefield incident - The view from a UK risk assessment engineer," J. Loss Prev. Process Ind., vol. 23, no. 6, pp. 913-920, 2010.

[6] D. M. Johnson, "The potential for vapour cloud explosions - Lessons from the Buncefield accident," J. Loss Prev. Process Ind., vol. 23, no. 6, pp. 921-927, 2010.

[7] A. D. Little, Risks from gasoline pipelines. Contract research report 206/1999. Sudbury, UK: HSE Books, 1999.

[8] J. Mather and I. G. Lines, Assessing the risk from gasoline pipelines in United Kingdom based on a review of historical experience. Contract Research Report 210/1999. Sudbury, UK: HSE Books, 1999.

[9] P. Kinsman and J. Lewis, "Report on a second study of pipeline accidents using the Health and Safety Executive's risk assessment programs MISHAP and PIPERS," HSE Books, Sudbury, UK, 2002.

[10] M. Dziubinski, M. Fratczak, and A. S. Markowski, "Aspects of risk analysis associated with major failures of fuel pipelines," J. Loss Prev. Process Ind., vol. 19, no. 5, pp. 399-408, 2006.

[11] S. Bonvicini, G. Antonioni, P. Morra, and V. Cozzani, "Quantitative assessment of environmental risk due to accidental spills from onshore pipelines," Process Saf. Environ. Prot., vol. 93, pp. 31-49, 2015. 
[12] S. B. da Cunha, "A review of quantitative risk assessment of onshore pipelines," J. Loss Prev. Process Ind., vol. 44, pp. 282-298, 2016.

[13] J. Giovanni Ramirez-Camacho, F. Carbone, E. Pastor, R. Bubbico, and J. Casal, "Assessing the consequences of pipeline accidents to support land-use planning," Saf. Sci., vol. 97, pp. 34-42, 2017.

[14] G. Atkinson and M. Pursell, "Vapour Cloud Development in Overfilling Incidents. FABIG Technical Note TN12," The Steel Construction Institute, Berkshire, UK, 2013.

[15] G. Atkinson and S. Coldrick, "Vapour cloud formation. Experiments and modelling. Reseach Report RR908," Health and Safety Executive, Derbyshire, UK, 2012.

[16] S. Lewis, "An overview of leading software tools for QRA," in 7th Professional Development Conference \& Exhibition, 2005.

[17] K. Ham et al., "Benchmark exercise on risk assessment methods applied to a virtual hydrogen refuelling station," Int. J. Hydrogen Energy, vol. 36, no. 3, pp. 2666-2677, 2011.

[18] F. H. Hedlund, "The extreme carbon dioxide outburst at the Menzengraben potash mine 7 July 1953," Saf. Sci., vol. 50, no. 3, pp. 537-553, 2012.

[19] H. W. M. Witlox, M. Harper, A. Oke, and J. Stene, "Validation of discharge and atmospheric dispersion for unpressurised and pressurised carbon dioxide releases," Process Saf. Environ. Prot., vol. 92, no. 1, pp. 3-16, 2014.

[20] H. W. M. Witlox, M. Harper, and R. Pitblado, "Validation of PHAST Dispersion Model as Required for USA LNG Siting Applications," Chem. Eng. Trans., vol. 31, pp. 49-54, 2013.

[21] R. J. Bettis, S. F. Jagger, H. W. M. Witlox, and M. Harper, “Twophase jet releases, droplet dispersion and rainout, II. Rainout experiments," J. Loss Prev. Process Ind., vol. 26, no. 3, pp. 462-467, 2013.

[22] H. W. M. Witlox and M. Harper, "Two-phase jet releases, droplet dispersion and rainout I. Overview and model validation," J. Loss Prev. Process Ind., vol. 26, no. 3, pp. 453-461, 2013.

[23] G. Atkinson, S. Coldrick, S. Gant, and L. Cusco, "Flammable vapor cloud generation from overfilling tanks: Learning the lessons from Buncefield," J. Loss Prev. Process Ind., vol. 35, pp. 329-338, 2015. 
[24] DNV GL AS, "PHAST software technical documentation," PHAST Tech. Doc., 2017.

[25] D. W. Johnson and J. L. Woodward, Release : A model with data to predict aerosol rainout in accidental releases. A CCPS concept book. New York, USA: Center for Chemical Process Safety CCPS/AIChE, 1999.

[26] J. L. Woodward, J. Cook, and A. Papadourakis, "Modeling and validation of a dispersing aerosol jet," J. Hazard. Mater., vol. 44, no. 2-3, pp. 185-207, 1995.

[27] R. L. Rowley, W. V. Wilding, J. Oscarson, L., T. A. Knotts, and N. F. Giles, "DIPPR ${ }^{\circledR}$ Data Compilation of Pure Chemical Properties," Design Institute for Physical Properties, AIChE, New York, USA, 2014.

[28] Anon., "MATLAB," The MathWorks, Inc., Natick, Massachusetts, United States, 2017.

[29] O. Kunz and W. Wagner, "The GERG-2008 wide-range equation of state for natural gases and other mixtures: An expansion of GERG2004," J. Chem. Eng. Data, vol. 57, no. 11, pp. 3032-3091, 2012.

[30] H. W. M. Witlox and A. Holt, Unified dispersion model-Technical reference manual. 1999.

[31] CEN, "EN 228:2017 Automotive fuels - Unleaded petrol Requirements and test methods," European Committee for Standardization (CEN), Brussel, 2017.

[32] E. Lemmon, M. Huber, and M. McLinden, "Reference fluid thermodynamic and transport properties-REFPROP, standard reference database 23, version 8.0, National Institute of Standard and Technology;", 2007.

[33] G. Atkinson, E. Cowpe, J. Halliday, and D. Painter, "A review of very large vapour cloud explosions: Cloud formation and explosion severity," J. Loss Prev. Process Ind., vol. 48, pp. 367-375, 2017.

[34] G. Atkinson, "Development of heavy vapour clouds in very low wind speeds," J. Loss Prev. Process Ind., vol. 48, pp. 162-172, 2017.

[35] F. H. Hedlund and H. B. Andersen, "Institutional support of learning from accidents: Some obstacles to getting a useful community-wide database in the EU," in Society of Risk Analysis, SRA Europe, Annual Conference 2016, 2006, pp. 1-21. 
[36] M. S. Mannan, "A technical analysis of the Buncefield explosion and fire," Institution of Chemical Engineers Symposium Series, no. 155. Institution of Chemical Engineers, pp. 662-673, 2009.

[37] G. Atkinson, J. Hall, and A. McGillivray, "Review of Vapour Cloud Explosion Incidents," Health and Safety Executive, Buxton, UK, 2017.

[38] T. A. Kletz, "Will cold petrol explode in the open air?," Chem. Eng., p. 63, 1986.

[39] M. S. Mannan, "The Buncefield Explosion and Fire-Lessons Learned," Process Saf. Prog., vol. 30, no. 2, pp. 138-142, 2011.

[40] J. F. Lechaudel and Y. Mouilleau, "Assessment of an accidental vapour cloud explosion a case study: Saint Herblain, October the 7th 1991, France," in Loss Prevention and Safety Promotion in the Process Industries, Proceedings of the 8th International Symposium, Antwerp, Belgium, June 6-9, 1995, 1995, pp. 377-388.

[41] D. M. Johnson, "Vapour cloud explosion at the IOC terminal in Jaipur,” Inst. Chem. Eng. Symp. Ser., no. 158, pp. 556-564, 2012.

[42] NTSB, "Pipeline Rupture and Subsequent Fire in Bellingham, Washington June 10, 1999. Pipeline Accident Report NTSB/PAR02/02," National Transportation Safety Board, Washington, DC., USA, 2002.

[43] T. Cutler and A. Barber, "Gasoline pipeline rupture and explosion at Whatcom Creek: A focus on response management," 2005 International Oil Spill Conference, Iosc 2005. Global Engineering Documents, pp. 3265-3270, 2005.

[44] D. W. Johnson and R. Diener, "Prediction of aerosol formation from the release of pressurized, superheated liquids to the atmosphere," Institution of Chemical Engineers Symposium Series, no. 124. Publ by Inst of Chemical Engineers, pp. 87-104, 1991.

[45] N. Pandya, N. Gabas, and E. Marsden, "Sensitivity analysis of Phast's atmospheric dispersion model for three toxic materials (nitric oxide, ammonia, chlorine)," J. Loss Prev. Process Ind., vol. 25, no. 1, pp. 20-32, 2012.

[46] S. E. Gant, A. Kelsey, K. McNally, H. W. M. Witlox, and M. Bilio, "Methodology for global sensitivity analysis of consequence models," J. Loss Prev. Process Ind., vol. 26, no. 4, pp. 792-802, 2013. 
[47] G. Sin, K. V. Gernaey, and A. Eliasson Lantz, "Good Modeling Practice for PAT Applications: Propagation of Input Uncertainty and Sensitivity Analysis," Biotechnol. Prog., vol. 25, pp. 1043-1053, 2009.

[48] M. Frenkel, R. D. Chirico, V. Diky, X. Yan, Q. Dong, and C. Muzny, "ThermoData Engine (TDE): Software Implementation of the Dynamic Data Evaluation Concept," J. Chem. Inf. Model., vol. 45, pp. 816-838, 2005.

[49] V. Diky et al., "ThermoData Engine (TDE): Software Implementation of the Dynamic Data Evaluation Concept. 8. Properties of Material Streams and Solvent Design," Chem. Inf. Model., vol. 53, pp. 249-266, 2013.

[50] R. Street, G. Z. Watters, and J. K. Vennard, Elementary fluid mechanics. Wiley, 1995.

[51] S. Mannan and F. P. Lees, "Chapter 15: Emission and dispersion," in Lees' Loss Prevention in the Process Industries, Elsevier, 2012, pp. 752-1074.

[52] R. Brown and J. L. York, "Sprays formed by flashing liquid jets," AIChE J., vol. 8, pp. 149-153, 1962.

[53] J. . Barrett and C. . Clement, "Growth rates for liquid drops," $J$. Aerosol Sci., vol. 19, pp. 223-242, 1988. 